\title{
"Las aventuras de Tendencio" en la revista Militancia Peronista para la Liberación: humor gráfico para la disputa peronista de los años 70
}

\section{"Las aventuras de Tendencio" in the magazine Militancia Peronista para la Liberación: graphic humor in the peronist dispute of the1970s.}

\author{
Mariela Stavale*
}

\begin{abstract}
Resumen:El artículo analiza una tira de humor gráfico publicada en la revista Militancia Peronista para la Liberación (1973-74) y busca dar cuenta de los procesos de simbolización de la experiencia histórica que significó el retorno del peronismo al poder. Para ello, se analizan las coyunturas conflictivas que hicieron que el peronismo revolucionario entre en crisis y la forma en que un personaje de humor gráfico llamado Tendencio personificó las disputas dentro del peronismo y las transformaciones en la identidad política de la revista.
\end{abstract}

Palabras clave: Peronismo, humor gráfico, Tendencio, movimientismo, Ortodoxio

\begin{abstract}
The article analyzes a strip of graphic humor published in the magazine Peronist Militancy for Liberation (1973-74) and seeks to account for the processes of symbolization of the historical experience that meant the return of Peronism to power. For this, we analyze the conflicting conjunctures that made revolutionary Peronism into crisis and the way in which a graphic humor character named Tendencio personified the disputes within Peronism and the transformations in the political identity of the magazine.
\end{abstract}

Keywords: Peronism, Tendencio, Movimientism, Ortodoxio

Recibido: 11 enero 2017

Aceptado: 27 marzo 2017

\footnotetext{
* Nacionalidad: Argentina, Licenciada en Sociología, Facultad de Humanidades y Cs. de la Educación, UNLP. Becaria de investigación doctoral por el Consejo Nacional de Investigaciones Científicas y Técnicas (CONICET). Este artículo se inscribe en mi investigación de posgrado en el marco del Doctorado en Ciencias Sociales de la UNLP. Pertenencia institucional: IdIHCS-CONICET, La Plata. Dir. Correo electrónico: mari_stavale@yahoo.com.ar
} 


\section{Introducción}

El siguiente artículo analiza el humor gráfico en la revista Militancia Peronista para la Liberación $(M P L)$, publicada en Argentina entre los años 1973-74'. Las publicaciones político-culturales se transforman en instrumentos clave para el análisis de los años 60 y $70^{\prime}$ dado que permiten recuperar los diferentes debates que atravesaron la experiencia de sus protagonistas. En Argentina, éstos giraron en torno a los ejes "peronismo, socialismo y revolución" 2 y las diferentes formas que asumió el triángulo según el peso de sus lados.

En términos generales, podemos afirmar que la historia reciente argentina se abre y cierra con dos golpes de Estado contra gobiernos peronistas: el primero en 1955, dio lugar a una etapa signada por la alternancia de gobiernos civiles/militares y por un proceso de politización y radicalización creciente, atravesado por la proscripción del peronismo y el exilio forzado de Perón a nivel nacional y por el impuso revolucionario que llegaba de Cuba y de los procesos de liberación en demás países del Tercer Mundo, a nivel internacional. Este escenario fomentó un conjunto de reorientaciones políticas que posibilitaron el mestizaje entre tradiciones como el peronismo (que se había proletarizado tras la caída del gobierno), el marxismo y el cristianismo, anteriormente impensadas al unísono. Junto con un proceso de modernización cultural creciente, fue consolidándose una "nueva izquierda" (NI) de composición heterogénea que compartió el lenguaje de la "revolución", la "lucha armada" y el "socialismo"3.

\footnotetext{
${ }^{1}$ Este artículo es producto del debate en torno a la ponencia "Las aventuras de Tendencio: analizando las transformaciones de la identidad política de la revista Militancia Peronista para la Liberación a través del humor gráfico" presentadas en las IX Jornadas de Sociología de la UNLP, Diciembre de 2016. A su vez, se inscribe en una investigación más amplia que analiza la experiencia político-editorial de las revistas Militancia Peronista para la Liberación y De Frente, publicadas entre 1973 y 1974.

${ }^{2}$ Tortti, M. Cristina (Dir), Chama, Mauricio y Celentano, Adrián (co-dir). La Nueza Izquierda Argentina. Socialismo, Peronismo y Revolución, 1955-1976, Rosario, Ediciones Prohistoria, 2014.

${ }^{3}$ Desde la izquierda, diversos sectores re-interpretaron al peronismo como un movimiento de liberación nacional con potencialidad revolucionaria al tiempo que profundizaban la convicción en torno a la lucha armada. Por su parte, algunos sectores del peronismo re-actualizaron sus banderas a partir del diálogo con el marxismo. Finalmente, sectores católicos rompieron con las estructuras tradicionales de la Iglesia en una radicalización que los vinculó fundamentalmente, con el peronismo. [Sobre experiencia de la clase obrera peronista: James, Daniel: Resistencia e integración. El peronismo y la clase trabajadora argentina 19461976, Buenos Aires, Editorial Siglo XXI, 2010; Sobre peronismo revolucionario: Bozza, Alberto. "La resignificación revolucionaria del peronismo y sus protagonistas durante la etapa de la proscripción", en: Tortti, M.C. (dir), Ibíd., pp.: 59-82 / Sobre tradiciones político-culturales y proceso de modernización cultural: Altamirano, Carlos, Peronismo y cultura de izquierda, Buenos Aires, Editorial Silgo XXI, 2001; Gilman, Claudia, Entre la pluma y el fusil, debates y dilemas del escritor revolucionario en América Latina, Buenos Aires, Editorial Siglo XXI, 2012 / Sobre Nueva Izquierda: Tortti, María Cristina. "Protesta social y nueva izquierda en la Argentina del Gran Acuerdo Nacional", en Pucciarelli, A (ed.), La primacía de la política. Lanusse, Perón y la Nueva Izquierda en tiempos del GAN, Buenos Aires, Eudeba, 1999, pp.: 205-230; Tortti, María Cristina. "La nueva izquierda argentina. La cuestión del peronismo y el tema de la revolución", en: Tortti, M.C. (dir), Ibíd., pp.: 15-34 / Sobre la radicalización del cristianismo: Lenci, María Laura. "Radicalización de los católicos en Argentina. Peronismo, cristianismo y revolución (1966-1971)", En: Cuadernos del CISH , Año 3, N 4, La Plata, 1998, pp.: 174-200]
} 
Aquí abordamos el retorno del peronismo al poder en 1973 y sus consecuencias para la izquierda peronista. Para ello, haremos hincapié en las coyunturas conflictivas que atravesaron al tercer gobierno peronista y la crisis que éstas abrieron dentro del peronismo revolucionario, agudizando contradicciones internas que tensionaron a todos sus actores. $M P L$ no se mantuvo ajena al debate; por el contrario sentó posiciones a partir de sus notas y secciones. Este artículo, se propone revisar la forma en que un personaje de humor gráfico llamado Tendencio personificó las disputas del peronismo y las transformaciones de la identidad política expresas en la revista; éste apareció en el noveno número, se mantuvo constante hasta su clausura y se convirtió en un ícono de $M P L$, con repercusiones importantes tanto dentro de la izquierda como entre los sectores de derecha.

Si bien MPL no se dedicó al humor gráfico -como si lo hicieron otras revistas coetáneas como Hortensia y Satiricón ${ }^{4}$ - el vínculo entre la violencia y el humor la atravesó, convirtiéndose en un recurso más a partir del cual el grupo político-editorial sentó posiciones en torno a la disputa política que se desplegó entre (y dentro de) la izquierda peronista y los sectores de la derecha del Movimiento, durante las agitadas aguas del tercer gobierno. Con este objetivo, analizaremos a Tendencio a partir de tres ejes. Los primeros dos se encuentran íntimamente vinculados y refieren al avance del estado de excepción ${ }^{5}$ durante el tercer gobierno peronista y a la disputa intra-partidaria: derecha vs. izquierda; esta tensión será analizada a partir del análisis comparado con otra tira cómica, publicada por la revista de derecha El Caudillo de la Tercera Posición $(E C)$, creada para "satirizar" a Tendencio a partir de noviembre de 1973. Finalmente, el tercer eje busca dar cuenta de los debates que la coyuntura abrió dentro de la izquierda peronista: las críticas que el personaje encarnó respecto de las organizaciones hegemónicas de la autodenominada "Tendencia Revolucionaria Peronista" -fundamentalmente, Montoneros y Juventud Peronista (JP) ${ }^{6}$.

\footnotetext{
${ }^{4}$ Sobre la revista Satiricón: Burkart, Mara: “De la libertad al infierno, La revista Satiricón (1972-1976)”, En: Gené, Marcela y Malosetti, Laura (comp.): Atrapados por la imagen. Arte y política en la cultura impresa argentina, Buenos Aires, Edhasa, 2013, Pp.: 307 - 338; "Caricaturas de Perón en Satiricón (1972-1974)", En: Papeles de Trabajo, Año 4, $\mathrm{N}^{\circ}$ 7, Buenos Aires, 2011, Pp.: 44-73; "Risa, sexo y censura política en la Argentina de los años setenta. La revista Satiricón (1972-1976)", en: III Congreso Internacional do Núcleo de Estudos das Américas, Río De Janeiro, 2012.

${ }^{5}$ Aquí utilizamos la noción "estado de Excepción" en el sentido que Marina Franco le otorga al concepto. La autora sugiere que lo interesante de esta categoría radica en que brinda la posibilidad de abrir perspectivas de análisis que van más allá de las dicotomías legalidad-ilegalidad o democracia-dictadura. Franco retoma el desarrollo teórico de Giorgio Agamben, quien -inspirado en un debate implícito entre Carl Schmitt y Walter Benjamin- lo define "como un umbral de indeterminación entre democracia y absolutismo", no necesariamente equiparable a regímenes democráticos o dictatoriales. La ventaja de esta forma de entender al estado de excepción radica en que la categoría expone el vínculo entre violencia y derecho, posibilita observar que es el propio Estado el que -a partir de una deriva de medidas represivas- construye la situación excepcional que paradójicamente, permite su conservación como tal y por estos motivos, se convierte en una herramienta útil para analizar la represión pre-golpe. [Franco, Marina. Un enemigo para la Nación. Orden interno, violencia y "subversión, 1973-1976, Buenos Aires, Fondo de Cultura Económica, 2012]

${ }^{6}$ El concepto de "Tendencia Revolucionaria del Peronismo" presenta la complejidad de ser una categoría nativa y analítica al mismo tiempo. Esta dualidad ha conducido, por ejemplo, a que el conjunto quede asimilado a Montoneros y Juventud Peronista por ser éstas sus organizaciones hegemónicas. Lejos de esta posición, aquí entendemos que "la Tendencia" fue un conjunto heterogéneo de sectores y organizaciones de
} 
El humor gráfico representa un tipo particular de discurso, con rasgos diferenciales, dado que presenta una carencia del sujeto discursivo: el "yo" que enuncia no tiene voz, no muestra su rostro y hasta puede no decir su nombre. Para que haya humor en un espacio de comunicación no conversacional -como el humor gráfico- es necesario superar la despersonalización del medio, asumiendo los rasgos del segmento socio-cultural que lee/consume la publicación ${ }^{7}$. Florencia Levin apunta que este tipo de discurso permite "acceder a la dimensión significativa dónde habitan y circulan representaciones sobre la política y los imaginarios sociales que las sostienen" y advierte que solo es posible decir algo más que el chiste una vez que se han entrecruzado diacrónica y sincrónicamente las viñetas humorísticas y los elementos contextuales que atraviesan al medio. ${ }^{8} \mathrm{~A}$ su vez, destaca otro aspecto característico: la conjunción entre la palabra escrita y el dibujo. Esta articulación puede presentarse de diversas maneras: una de ellas es el cartoon (o caricatura humorística); otra de sus formas es la tira cómica: estas presentan un mensaje gracioso en una secuencia de viñetas auto-inclusivas, con personajes estables que desarrollan temas a lo largo de varias ediciones.

El caso analizado asume la forma de una tira cómica: desde su aparición, Tendencio recorrió número a número las páginas de $M P L$ expresando los debates que atravesaron al peronismo en el período analizado. La caricatura condensó de una particular manera la ruptura con la experiencia del gobierno peronista, la disputa con los sectores de derecha dentro del Movimiento y las discusiones al interior de "la Tendencia".

Como veremos, Tendencio apeló al recurso retórico de la ironía que, en términos amplios, es un modo de discurso indirecto que supone una contradicción. La única forma de identificarla -y que produzca el efecto humorístico- es conociendo el contexto de la enunciación y las ideas de quien produce el enunciado: el intérprete no puede evitar la referencia a la intención del autor. ${ }^{9}$ A modo de ejemplo, el nombre Tendencio adelanta una contradicción irónica: la revista criticaba a las organizaciones hegemónicas de "la Tendencia" sin renunciar a ese espacio político y disputando posiciones dentro de él. En segundo lugar la tira apeló a la sátira política que -al igual que la burla- es constitutiva de cierta forma de ironía. La sátira puede definirse como una "ironía militante", sus normas morales son relativamente claras y le permite situarse en relación con lo grotesco y con lo absurdo. Mientras que la ironía propone una pregunta y se esfuerza por poner en entredicho verdades, la sátira impone una respuesta inferida como norma moral rígida ${ }^{10}$. En este punto, es posible aventurar que la sátira política tendrá presencia en las críticas que Tendencio expresó sobre la derecha peronista.

la izquierda peronista que si no se alinearon a Montoneros-JP discutieron sus posiciones y buscaron disputar espacios de poder en su interior, a través de posicionamientos propios.

${ }^{7}$ Steimberg, Oscar. "Sobre algunos temas y problemas del análisis del humor gráfico", En: Signo y seña, Facultad de Filosofía y Letras UBA, Buenos Aires, 2001, Pp.: 4-6.

${ }^{8}$ Levin, Florencia. Humor Político en tiempos de represión. Clarín, 1973-1983, Buenos Aires, Siglo XXI, 2013, P.: 20-21.

${ }^{9}$ Schoentjes, Pierre. Política de la Ironía, Paris, Ediciones du Seuil, 2001, P.:129.

${ }^{10}$ Schoentjes, Pierre, op. cit., P.: 183. 
Siguiendo a Schoentjes observamos que cuando la ironía surge del discurso, sus dimensiones no deben separarse de los aspectos sociales, culturales e históricos del contexto en el que se emplea, es decir, del marco político en el que se inscribe ${ }^{11}$. Por eso, repasaremos algunos aspectos clave del contexto en el que surgió $M P L$, los debates que expresó y sus aspectos formales.

\section{La Militancia en contexto: Coyuntura política y aspectos formales}

Bajo la coyuntura autoritaria de un nuevo golpe de Estado que 1966 irrumpió en la vida política argentina, el proceso de radicalización creció. En 1969 la insurrección popular conocida como el Cordobazo, aceleró el ciclo de protesta y fomentó el surgimiento de las organizaciones armadas, relegando cualquier discusión en torno a las diferencias dentro de la NI hermanada por la impugnación a un régimen viciado y autoritario ${ }^{12}$. A principios de los 70’ ya actuaban las principales organizaciones revolucionarias del peronismo: Fuerzas Armadas Peronistas (FAP), Montoneros, Juventud Peronista (JP), Peronismo de Base (PB), etc. $^{13}$

En 1971, el Gral. Agustín Lanusse asumió el gobierno y buscó encauzar la crisis relegitimando el rol del Estado e incorporando al peronismo en el juego político legal. El regreso del peronismo al poder hizo estallar las disputas por el control del proceso entre múltiples sectores que postulaban distintas interpretaciones de la tradición peronista y de la palabra del líder ${ }^{14}$. Dentro del peronismo de izquierda se abrieron debates que durante la dictadura, habían sido relegados por una unidad inestable en torno a acuerdos mínimos: la difusa idea de que Perón y el peronismo eran revolucionarios. Sus organizaciones armadas habían luchado por el retorno del líder pero éste en vez de lograrse por la vía armada, se resolvía a partir de la legalización del Movimiento, desde la lógica democrático-burguesa ${ }^{15}$.

La coyuntura obligaba a que las organizaciones peronistas respondieran por el proyecto político que defendían, generando divisiones en torno a definiciones ausentes que comprometían aspectos clave como el carácter del Movimiento, el rol de Perón y la caracterización del proceso revolucionario. La crisis de aquellos acuerdos mínimos tuvo por resultado la consolidación de dos posturas diferentes que pueden considerarse como tipos ideales, ya que raramente se daban en estado puro debido a la heterogeneidad interna de las

\footnotetext{
${ }^{11}$ Schoentjes, Pierre, op. cit. P.: 247.

12 Tortti, M.C. Ibid, P.: 17.

${ }^{13}$ Entre las organizaciones armadas de la izquierda guevarista: Partido Revolucionario de los Trabajadores Ejército Revolucionario del Pueblo (PRT-ERP), Fuerzas Armadas de Liberación (FAL), Fuerzas Armadas Revolucionarias (FAR), etc. Con la pronta peronización de las FAR, el ERP devino en organización hegemónica dentro de la izquierda no peronista.

${ }^{14}$ De Riz, Liliana. La política en suspenso, 1966/1976, Buenos Aires, Paidós, 2000; Sigal, Silvia y Verón, Eliseo, Perón o muerte. Los fundamentos discursivos del fenómeno peronista, Buenos Aires, Legasa, 2003; Franco, Marina, op. cit.

${ }^{15}$ Lenci, María Laura "Cámpora al gobierno, Perón al poder. La tendencia revolucionaria del peronismo ante las elecciones del 11 de Marzo de 1973” En: Pucciarelli, A (ed.), Ibíd., Pp.: 167- 201
} 
organizaciones peronistas y la variación de sus planteos a lo largo del tiempo ${ }^{16}$. La primera fue la posición movimientista, que acentuaba el carácter nacional de la revolución vinculándola a la liberación nacional sin que ésta implique necesariamente, liberación social. Se consideraba que tanto Perón como su Movimiento eran revolucionarios y aunque denunciaban la existencia de "traidores" en su interior, las diferencias eran puestas en segundo lugar, priorizando la unidad del peronismo. Enfrentando a esta postura, se erigía el alternativismo que consolidaba una posición clasista y afirmaba que no habría liberación nacional sin revolución social. Remarcaban la existencia de contradicciones irreconciliables al interior del Movimiento expresadas en las burocracias sindicales-políticas y en la pretensión de una alianza imposible con la burguesía nacional. La clase obrera era el sujeto revolucionario y se postulaba la necesidad de construir una Alternativa Independiente (AI) al Movimiento. Si bien no se tornaba explícito, Perón "ya no era considerado como un líder revolucionario, aunque podría conducir al menos parte del proceso" $"$.

El debate entre movimientistas y alternativistas atravesó a la izquierda peronista desde 1971 en adelante, impidiendo su unidad estratégica ${ }^{18}$. La corriente movimientista se nutrió de las posiciones de Montoneros y JP, que funcionaron como fuerza centrífuga, atrayendo para sí a las fracciones que rechazaron el alternativismo. Por su parte, esta corriente fue minoritaria dentro de "la Tendencia" y quedó representada por las FAP, el PB y escisiones de Montoneros como la Columna José Sabino Navarro, entre las más relevantes.

Los medios político-culturales alineados al peronismo revolucionario no se mantuvieron ajenos a este debate. En el caso de $M P L$, la revista publicó su primer número en Junio de 1973 y circuló semanalmente hasta marzo de 1974, publicando 38 números.

\footnotetext{
${ }^{16}$ González Canosa, Mora. "Las Organizaciones Armadas Peronistas (OAP): un análisis comparativo de los (re) posicionamientos de las FAR", en: Tortti, M. C. (dir), Ibíd., Pp.:131- 156, p.: 140.

${ }^{17}$ González Canosa, Mora, Ídem, P.: 140 / Tanto González Canosa como Lucas Lanusse plantean que el movimientismo y el alternativismo pueden ser comprendidos desde una construcción típico-ideal. Lanusse introduce un tipo ideal intermedio que denomina tendencista y refiere a quienes sostenían diferencias irreconciliables dentro del Movimiento pero le reconocían potencialidad, llamando a la conformación de la Tendencia Revolucionaria [Lanusse, Lucas, Montoneros. El mito de sus 12 fundadores, Buenos Aires, Editorial Vergara, 2005, P.: 255]. Aquí se descarta la denominación "tendencista" dado que se considera que la categoría corre el riesgo de reducir a "la Tendencia" a un sector determinado, obviando a los demás sectores que la compusieron y los debates que la atravesaron.

${ }^{18} \mathrm{La}$ discusión tensionó a sus organizaciones más influyentes: las FAP y Montoneros En las FAP, el debate fue propugnado por la Conducción Nacional transformada por la entrada de militantes provenientes del sindicalismo combativo y el clasismo, claves para el lanzamiento de la AI, corriente que fraccionó a la organización y se extendió más allá de sus fronteras. En 1972, la discusión llegó a Montoneros pero allí no fue impulsada por los espacios de conducción sino por un grupo reducido de hombres, presos tras el fracaso de la toma de la localidad de La Calera en 1970. Este grupo escribió un documento (auto) crítico que fue rechazado por la Organización, dando lugar a su primer desgajamiento: La Columna José Sabino Navarro, organización que formó parte del alternativismo junto con las FAP Comando Nacional, el Peronismo de Base, entre otras. [González Canosa, Ídem; Seminara, Luciana. "Escribir las prácticas. Diálogos implícitos entre Montoneros y la organización Sabino Navarro", En: Travesía 16, Tucumán, 2014, Pp.: 103-132; "Pliegues en el relato de la Historia Reciente Argentina: la experiencia de la Organización Montoneros Sabino Navarro (1972-1975)", En: Izquierdas N 16, Santiago de Chile, 2013, Pp.: 140-155]
} 
MPL estuvo dirigida por Rodolfo Ortega Peña, Eduardo Luis Duhalde y los hermanos de éste: Carlos María y Marcelo; pero el grupo político que conformó la revista desbordaba al equipo editorial: estaba compuesto por intelectuales, abogados y militantes que participaban directa o indirectamente de ella y que venían transitando un camino político común $^{19}$ que buscaba la unidad revolucionaria entre organizaciones peronistas y marxistas en torno a un frente político revolucionario. Esta composición política fue expresiva de una "impronta de peronización" 20 que dio cuenta de una relación fluida entre peronismo y marxismo: éste, situado en el lugar de la teoría, era concebido como una herramienta para analizar la sociedad. La identidad política se definía peronista y revolucionaria, se articulaba en torno a la experiencia de la clase obrera y del pueblo y entendía que "ningún verdadero marxista" podía ubicarse por fuera del movimiento de masas ${ }^{21}$. Esta impronta tendrá una particular influencia en la articulación peronismo-revolución: la liberación nacional aparecía intrínsecamente vinculada a la social, definición que conducía a analizar las contradicciones de clase existentes dentro y fuera del Movimiento, como elementos clave.

Con estos lineamientos, MPL se acercó al alternativismo y tensionó hacia el extremo las fronteras de su identidad peronista, al acentuar el carácter clasista de sus planteos. Si bien fue una publicación "independiente" que no forjó relación orgánica con organizaciones revolucionarias, sí asumió un vínculo político-ideológico que la alineó con ésta corriente. Este posicionamiento fue clave no solo hacia adentro de la Tendencia, sino también respecto del conflicto intra-partidario que atravesó al peronismo en general. El alternativismo de MPL la enfrentó abierta y tempranamente con los sectores de la derecha peronista que -apoyada por Perón, quien inclinó la balanza a su favor una vez consumado su regreso- ensanchó su poder dentro del Movimiento y ganó espacios dentro del gobierno.

\footnotetext{
${ }^{19}$ Entre los miembros del grupo político: Vicente Zito Lema, Mario Hernández, Roberto Sinigalgia, Ignacio Vélez, Carlos González Gartland, Ricardo Carpani, Diego Muñiz Barreto, Alicia Auguren, Mónica Peralta Ramos, Rubén Dri etc. Muchos formaron parte de "la Gremial de Abogados" a partir de la cual aceitaron el vínculo con las organizaciones armadas peronistas y de izquierda. A su vez, el grupo contaba con la colaboración de organizaciones como FAP, PB, Columna José Sabino Navarro y la organización guevarista ERP que había ayudado a financiar la revista.

${ }^{20}$ Con "impronta de peronización" refiero a las experiencias previas de grupos y sectores del peronismo revolucionario que pusieron en juego de diferencial manera articulaciones entre elementos de la tradición peronista y otras tradiciones político-culturales como el marxismo, el cristianismo, etc. Estas diferentes articulaciones pueden arrojar luz sobre la forma en que los sectores del peronismo revolucionario (re) definieron la identidad peronista y su vínculo con la revolución. (Stavale, Mariela. "Peronismo para la Liberación Nacional ¿y social? El vínculo peronismo-revolución en las revistas Militancia Peronista para la Liberación y Envido, 1973”, En: Contemporánea Año 6, Vol. 7, Montevideo, 2016)

${ }^{21}$ El grupo reconocía entre sus "maestros" a Hernández Arregui, Puiggrós, etc. -personalidades claves en el vínculo entre las tradiciones marxista, nacionalista y peronista- y se reivindicaban herederos de J.W. Cooke quien a demás, había sido el nexo político con la experiencia cubana / La idea de un "marxismo situado" es desarrollada por González Canosa al re-pensar la "peronización de las FAR". [González Canosa, M. "Políticas de construcción del peronismo. El discurso de las FAR en los albores de la década del setenta en Argentina" En: Tempo \& Argumento, Vol. 7, N 14, Florianópolis, 2015]
} 
Tendencio se aventuró en $M P L$ y persistió en sus páginas, refiriendo a estos debates a través del humor y expresando el proceso de transformación identitaria que atravesó al grupo político-editorial durante toda la etapa.

Las aventuras de Tendencio frente el avance del estado de excepción, la "derechización" del peronismo gobernante y la ruptura con Perón

La revista $M P L$ publicó su primer número a pocos días de que Cámpora asumiera la presidencia encarnando el retorno del peronismo al gobierno. Expresiva de un sector del peronismo revolucionario, acompañó esta primera etapa cargándola de sentidos revolucionarios al entenderla como un primer paso hacia la liberación nacional y social ${ }^{22}$. Sin embargo, este momento inicial duró poco y la revista comenzó a expresar signos de distanciamiento con el gobierno y con Perón. Su tercer número -publicado el 28 de Junioretrató la masacre de Ezeiza, acontecimiento que simbolizó el comienzo de las disputas por el poder dentro del peronismo, entre sus diferentes sectores. Perón regresaba al país tras 18 años de exilio y fue esperado en el Aeropuerto de Ezeiza por una de las concentraciones populares más grandes de la historia argentina. Allí, los sectores de derecha del peronismo desataron un enfrentamiento contra la izquierda peronista liderada por JP y Montoneros ${ }^{23}$.

Estos hechos agrietaron tempranamente la posición de $M P L$ respecto de Perón. Si bien en este momento inicial la revista evitó la confrontación directa con el líder, sus análisis adelantaban signos de quiebre en la identidad peronista del grupo político-editorial. El primer resquebrajamiento importante se dio tras la forzada renuncia de Cámpora, el 13 de Julio de 1973. Este último hecho dio lugar a que en Setiembre se celebraran nuevas elecciones dónde Perón triunfó con el $62 \%$ de los votos. Entre ambos, gobernó interinamente Raúl Lastiri, presidente de la Cámara de Diputados, que tuvo dos objetivos tendientes a lograr la llegada de Perón: garantizar elecciones rápidas y "depurar" la administración de todo elemento cercano a "la Tendencia".

La revista interpretó la renuncia de Cámpora como un "golpe de Estado inventado por Lastiri" 24 y denunció el avance de los sectores de la burocracia sindical-política y la presencia de "los comandantes en jefe de las Fuerzas Armadas" quienes habían vuelto a "la actividad política [a través de] radiogramas, reuniones con dirigentes políticos, decisiones en las que participaron y todo lo que corresponde a las desagradables experiencias argentinas, en lo que refiere a la intervención militar en la cosa pública" ${ }^{25}$.

En este contexto de crisis Tendencio realizó su primera aparición, el 9 de Agosto de 1973. El dibujito de trazos simples salió publicado como un boceto suelto en el cuerpo de la

\footnotetext{
${ }^{22}$ Militancia Peronista para la Liberación 1, 14 de Junio de 1973, P.: 3. En: www.eltopoblindado.com

${ }^{23}$ Franco, Marina, op. cit., P.: 46 y 50

${ }^{24}$ Militancia Peronista para la Liberación $N^{\circ}$ 6, 19 de Julio de 1973, P: 4

Esta interpretación se encontró más cerca de las interpretaciones de la izquierda marxista-guevarista que de los sectores hegemónicos del peronismo revolucionario. El PRT-ERP caracterizó el hecho como un "autogolpe contrarrevolucionario".

${ }^{25}$ Militancia Peronista para la Liberación N 6 , Pp.: 3-6.
} 
revista, sin nombre y sin presencia en el sumario de secciones. Sin embargo, el impacto y repercusión del personaje lo transformó en una de las secciones fijas más importantes. A partir del número 11 es incorporado al sumario bajo el nombre Tendencio y sistematizado como sección. Marcelo Duhalde (miembro del equipo de MPL) recuerda que "Tendencio fue un hallazgo casual porque Eduardo y mi hermano Carlos eran buenos dibujantes (...) un día Eduardo hizo algo que nos pareció digno de ser publicado, y entonces ahí apareció Tendencio". La sección estuvo a cargo de Eduardo Duhalde aunque a veces, contara con el aporte de Ortega Peña o alguno de sus hermanos. ${ }^{26}$

En esta primera aparición, Tendencio irrumpía en la página 21 sin nombre ni carta de presentación, sosteniendo una pancarta que apuntaba: "Mongo y Aurelio son nuestros compañeros"27 [Fig. 1]. El dibujito retomaba el discurso que Perón había pronunciado frente a los gobernadores el 2 de Agosto, en dónde había cuestionado a la Juventud y avanzaba contra la guerrilla, al caracterizarla como "un asunto que la ley no tolera, y que en consecuencia nosotros no podemos tolerar. Nosotros no le ponemos ningún inconveniente, si ese partido político -se llame Comunista, se llame E.R.P. o se llame Mongo Aurelio quiere funcionar dentro de la ley (...) En lo que sea fuera de la ley, es la Justicia y la Policía las que deben entender" 28

Irónicamente, el dibujo planteaba un distanciamiento respecto del líder y una identificación con los sectores que éste estaba dejando afuera de la legalidad -y de la órbita peronista. En efecto, el personaje se alineaba con el análisis que el número ofrecía respecto de este discurso. En el editorial, titulado "No hay peronismo sin Perón, pero tampoco Perón sin peronismo", el grupo político alertaba sobre el peligro de tomar la palabra del líder como "verdad revelada al estilo papal" apuntando que

No renunciamos a reivindicar los objetivos estratégicos, los métodos de lucha, los mártires y los soldados del pueblo (...) Continuaremos planteando la toma del Poder (...) nuestra clase trabajadora no se inquieta demasiado por los discursos que puedan pronunciarse. Sí, en cambio, advierte de inmediato cuando un proyecto político no le es favorable ${ }^{29}$

Más adelante apuntaban que Perón había desplazado a "la Tendencia" al definir su Movimiento como de izquierda, dejándola "tan al costado que casi se encuentra fuera de esa geográfica descripción política" ${ }^{30}$ En línea con este distanciamiento respecto del gobierno peronista y buscando profundizar las críticas, el personaje volvía a aparecer en el número 10 -aunque todavía sin referencia. En esta oportunidad, Tendencio incorporaba el mate -infusión popular típica- como rasgo permanente y dialogaba con un nuevo personaje que, simulando ser un pirata (parche en el ojo, pata de palo y escopeta en mano) le

\footnotetext{
${ }^{26}$ Testimonio de Marcelo Duhalde en entrevista con la autora, La Plata, 2014

${ }^{27}$ Militancia Peronista para la Liberación $\mathrm{N}^{\circ}$ 9, 9 de Agosto de 1973, P.: 21

${ }^{28}$ Perón, Juan Domingo. "Discurso a los gobernadores", 2 de Agosto de 1973. En: www.ruinasdigitales.com

${ }^{29}$ Militancia Peronista para la Liberación $\mathrm{N}^{\circ} 9, \mathrm{P} .: 3$

${ }^{30}$ Militancia Peronista para la Liberación $N^{\circ} 9$, P.: 8
} 
preguntaba: “¿Cómo adivinó que estoy en el Ministerio del Pueblo?”31. La viñeta refería al Ministerio de Bienestar Social dirigido por José López Rega (personaje clave de la derecha peronista) y se publicaba junto a una nota dónde $M P L$ denunciaba la entrada de patotas que -vinculadas al Ministerio- habían amedrentado en las villas dónde el Movimiento Villero Peronista (ligado a la Tendencia) tenía trabajo territorial.

Recién en el número 11, Tendencio contó con una presentación oficial [Fig. 2]. La viñeta aparecía en la página 7 junto a una aclaración del editorial a cerca de su incorporación al staff de $M P L$ :

Tendencio hizo su aparición en Militancia hace tres números. De inmediato, aquellos que carecen del sentido del humor, o lo que es peor, prefieren negar la verdad cruda de la realidad política, lo hicieron objeto de las más duras críticas. Fue cuando Tendencio exclamó orgulloso: "iyo también estoy cuestionado!". Y como Militancia no es "presionable", Tendencio sigue en sus páginas. ${ }^{32}$

En esta tercera publicación, la revista seguía aludiendo al discurso de Perón quien había cuestionado a la Juventud. El personaje venía por partida doble: en el primer cuadro, Tendencio miraba al lector mientras sostenía una pancarta en dónde exclamaba: "Yessi, compadre". En el segundo, sin cabeza -es decir, "descabezado"- se dirigía a otro personaje igual a él afirmando: "¡que burocracia, ni burocracia!... ¡Estamos más fuertes que nunca! ${ }^{33}$ ". Ácido y burlón, Tendencio comenzaba a revelarse como un personaje que iba adquiriendo vida propia, que encarnaba un "nosotros" afín a una identidad peronista y revolucionaria y desde allí, satirizaba el avance de la burocracia político-sindical dentro del Movimiento y del gobierno, deslizando también una crítica al movimientismo montonero que seguía caracterizando la contradicción con la burocracia como secundaria. La referencia a Julio Yessi se replicaba en la sección Cárcel del Pueblo, dónde la revista encarcelaba editorialmente a personajes, medios o conceptos considerados contrarios a la voluntad revolucionaria del pueblo y de la clase obrera. En la cárcel de este número el prisionero era Yessi quien, como integrante del Consejo Superior de la rama Juvenil del Movimiento, era acusado de "asesor del brujo José López Rega, convirtiéndose en la plomada de la "F.J.P" (Falsa Juventud Peronista), instrumentada desde Bienestar Social para destruir a la auténtica juventud" 34

Este distanciamiento siguió profundizándose con fuerza y la tira cómica se complejizó con cada publicación. En este punto, Septiembre fue un mes clave no sólo porque se produjeron las elecciones que consagraron la fórmula Perón-María Estela Martínez de Perón ("Isabel”) vitoreada por la derecha peronista y vapuleada por Montoneros-JP (que había propuesto a Cámpora como vicepresidente) sino porque el 25 de

\footnotetext{
${ }^{31}$ Militancia Peronista para la Liberación $\mathrm{N}^{\circ}$ 10, 16 de Agosto de 1973, P.: 22

${ }^{32}$ Militancia Peronista para la Liberación $\mathrm{N}^{\circ}$ 11, 23 de Agosto de 1973, P.: 7

${ }^{33}$ Militancia Peronista para la Liberación $\mathrm{N}^{\circ} 11$, P.: 7

${ }^{34}$ Militancia Peronista para la Liberación $\mathrm{N}^{\circ} 11$, P.: 37
} 
ese mes, a horas del triunfo electoral, Montoneros "ajustició" a José Ignacio Rucci dirigente de la CGT y pieza clave del programa económico del gobierno- como una forma de obligar al líder a negociar con la organización ${ }^{35}$. Lejos de ello, la muerte del dirigente sindical trajo por consecuencia el avance represivo de una derecha peronista que -avalada por Perón- se propuso depurar al Movimiento. El hecho materializa el segundo (y definitivo) quiebre de la identidad política de $M P L$ que, a partir de este momento, se alineó con firmeza a la Alternativa Independiente y cuestionó explícitamente a Perón, al Movimiento y a su gobierno.

El número 16 se publicó el 27 de Septiembre: la cercanía con el "ajusticiamiento" a Rucci explica porqué la revista no se refería a los hechos. En esta oportunidad, la tira cómica de MPL presentaba a un nuevo personaje llamado Moderato, el hijo de Tendencio [Fig. 3]. La incorporación aparecía tras el triunfo de Perón, quien había ganado con más del 50 por ciento de los votos. A los ojos de $M P L$, el apoyo indiscutido del pueblo eximía al gobierno (y a Perón) de cualquier excusa para retrasar el proceso transformador, obligándolo a cumplir con el programa del 11 de Marzo: la construcción de "la Patria Socialista" ${ }^{36}$.

En esta nueva coyuntura, Moderato irrumpía a través de un diálogo con su padre, a quien le preguntaba: "Papi, ¿que quiere decir "larga y prolongada"?; Tendencio respondía con seguridad: "la cola del kerosene, hijo" ${ }^{37}$. La pregunta refería a la estrategia revolucionaria de guerra popular y prolongada y la respuesta adelantaba una situación política a punto de explotar. Irónicamente, ya había estallado y se reflejó en el número siguiente dónde $M P L$ analizó la muerte de Rucci y el avance de la derecha materializada en la publicación del Documento Reservado $\mathrm{N}^{\circ} 1$ (DR1) a partir del cual el peronismo (y Perón) ordenaban depurar al Movimiento, dando inicio a una lucha partidaria contra "la subversión"38. A partir de allí, MPL analizó la escalada represiva en términos de "terror blanco" o "terrorismo" perpetrado por el gobierno y el Estado. En el número 18 -publicado un día antes de que Perón asumiera la presidencia- la revista afirmaba: "la semana política estuvo marcada por la continuidad de la ofensiva que la derecha venía desarrollando. A partir de la muerte de Rucci, el terror blanco se instaló en Argentina transformándose en una forma común de expresión política"39

Perón asumió su cargo con un proyecto de "pacificación y reorganización institucional centrado en acuerdos partidarios y corporativos que denominó "Democracia

\footnotetext{
35 El programa económico conocido como "Pacto social" suponía la conciliación entre la clase obrera (representada por la CGT) y la "burguesía nacional" (representada por la CGE). El programa fue duramente cuestionado por $M P L$, quien descartaba la posibilidad de una alianza con la burguesía en la coyuntura de los años 70’ / En referencia a las intenciones de Montoneros respecto del "ajusticiamiento” a Rucci ver: Grassi, Ricardo, El Descamisado, periodismo sin aliento, Buenos Aires, Editorial Sudamericana, 2015; Slipak, Daniela, Las revistas montoneras. Como la organización construyó su identidad a través de sus publicaciones, Buenos Aires, Siglo XXI, 2015

${ }^{36}$ Militancia Peronista para la Liberación $\mathrm{N}^{\circ}$ 16, 27 de Septiembre de 1973, P.: 3.

${ }^{37}$ Militancia Peronista para la Liberación $\mathrm{N}^{\circ} 16,27$ de Septiembre, P.: 7

${ }^{38}$ La Opinión, 2 de Octubre de 1973.

${ }^{39}$ Militancia Peronista para la liberación $\mathrm{N}^{\circ}$ 18, 11 de Octubre de 1973, P.: 3
} 
Integrada" ${ }^{, 40}$. Los sectores revolucionarios eran considerados una amenaza y excluidos del Movimiento por el Consejo Superior Peronista, que tenía la capacidad de determinar quienes eran (o no) peronistas. Para noviembre, éste instrumento había adelantado que ni $M P L$, ni El Descamisado ni $Y a$ (revistas de "la Tendencia") lo eran. En el editorial del número 21, publicado el 1 de Noviembre, $M P L$ apuntaba que el avance de la burocracia político-sindical "ha intensificado en estos días su acción depuradora" acusando de marxistas infiltrados a Quieto y Firmenich, atacando como no peronistas a Cámpora y Obregón Cano (gobernador de Córdoba aliado a "la Tendencia") y descalificando como "agentes sinárquicos" a todos los que tengan que ver con las publicaciones mencionadas ${ }^{41}$. En diálogo con éste posicionamiento, Tendencio aparecía junto a su hijo quien le preguntaba: "Papi, ¿todos los que votaron a Cámpora en Marzo son marzistas?"42

Las páginas de $M P L$ reflejan la centralidad que había tomado la lucha dentro y fuera del peronismo, la espiral de violencia in crescendo y el avance de las políticas represivas. Irónica y confrontativa, MPL denunciaba la ausencia del pueblo, "del peronismo de abajo" en el gobierno de Perón, interpelándolo directamente. El editorial número 23 titulaba "Hablemos claro" y sostenía: "El General ha traído al país un preconcebido plan político que, por sus particularidades conciliacionistas, de "desensillar hasta que aclare", etc. se aviene para ser ejecutado por la burocracia traidora"43. La revista parafraseaba a Perón y denunciaba una política de conciliación con los sectores de la dictadura; el grupo ponía en juego una posición que disputaba el sentido de ser peronista con el propio líder del movimiento, afirmando que el cuestionamiento a la burocracia y "el aval que a la misma le otorga Perón" no podía obviarse con acusaciones de "infiltración o sinarquía" ${ }^{44}$. En esta línea, el número 26 publicado el 6 de Diciembre presentaba a Tendencio disfrazado de burócrata: con anteojos de sol, cigarro en la boca, remera a rayas y chaqueta. En esta oportunidad, Moderato le preguntaba qué era la burocracia, frente a lo cual respondía "Es muy difícil de explicar nene" 45

La "derechización" del gobierno se había consolidado y a finales del 73', el proyecto revolucionario parecía esfumarse. En su número 27, publicado el 13 de Diciembre, la revista titulaba "Un recuerdo lejano" a su sección "Semana Política", dónde continuaba denunciando la ofensiva burocrática contra las bases, contra las provincias con gobernadores a fines a la izquierda peronista y "las andanzas purificadoras" del Consejo que ahora atacaba al Ministerio de Educación, aplicando la recientemente aprobada Ley de Prescibindibilidad $^{46}$. Esta disposición legal facultaba a las autoridades superiores de la administración pública, empresas estatales o cualquier dependencia oficial a dejar prescindible al personal. A diferencia de MPL, la Juventud Trabajadora Peronista (JTP) -

\footnotetext{
${ }^{40}$ Franco, Marina, op. cit., P.: 43

${ }^{41}$ Militancia Peronista para la Liberación $N^{\circ} 21,1$ de Noviembre de 1973, P.: 3

${ }^{42}$ Militancia Peronista para la Liberación $\mathrm{N}^{\circ} 21, \mathrm{P} .: 7$

${ }^{43}$ Militancia Peronista para la Liberación $\mathrm{N}^{\circ} 23,15$ de Noviembre de 1973, P.: 3

${ }^{44}$ Militancia Peronista para la Liberación $\mathrm{N}^{\circ} 23, \mathrm{P} .: 3$

${ }^{45}$ Militancia Peronista para la Liberación $N^{\circ} 26,6$ de Diciembre de 1973, P.: 7

${ }^{46}$ Militancia Peronista para la Liberación $N^{\circ} 27,13$ de Diciembre de 1973, P.: 6
} 
estructura sindical de la JP- apoyó la ley desde un concepto abstracto (suponiendo que existía un gobierno popular). A sus ojos, ésta legislación permitía prescindir de personajes vinculados a la Dictadura "enquistados" en sus cargos públicos ${ }^{47}$. Sin embargo, en la práctica, la Ley fue un instrumento para amenazar y mantener a raya a los trabajadores y a la militancia revolucionaria. En ésta oportunidad, Tendencio aparecía con un golpe en la cara y su hijo Moderato exclamaba: "¡Otra vez se te escapó la palabra socialista!"48.

El último número del año, publicado el 27 de diciembre, retomaba aquella línea pero con una especificidad que indicaba que Tendencio, lejos de ser una expresión transparente de la discusión que el grupo político-editorial estaba encarnando con el resto del peronismo, había adquirido un rol activo que la modificaba y constituía: el personaje llegaba hasta la tapa de la revista equiparado a personalidades de peso que, como Perón, Cooke, Eva, habían protagonizado portadas anteriores. Para el caso analizado, Tendencio aparecía en diferentes momentos deseando feliz navidad y año nuevo hasta que en la cuarta viñeta, dejaba el mate y se retiraba para asomarse gritando "Feliz Patria Socialista". En el último recuadro, afirmaba satisfecho "¡Lo dije!" con la expresión de quien realiza una osadía. $^{49}$

El avance del Estado de excepción dio un salto en Enero de 1974, tras la reforma al Código Penal promulgada desde el gobierno. El puntapié para la aprobación del código había sido el ataque al Regimiento de Caballería número 10 con asiento en Azul, protagonizado por la organización guevarista Ejército Revolucionario del Pueblo (ERP). Esta situación significó un endurecimiento sustantivo de las penas (incluso más allá de lo hecho por la dictadura de Onganía), creando políticas tendientes a garantizar la "seguridad nacional" a través de la represión del "terrorismo" y la "subversión" también sirvió de excusa para que Perón avanzara contra el gobernador de Buenos Aires, Oscar Bidegain, que fue cuestionado por su simpatía con los sectores revolucionarios, obligándolo a renunciar. Esta será la primera de una suerte de intervenciones provinciales, que pondrán fin a aquellos gobiernos afines a "la Tendencia". En el número 36 del 7 de Marzo, Tendencio refería al levantamiento policial conocido como "el navarrazo" que, avalado por el Poder Ejecutivo, puso fin al gobierno cordobés de Obregón Cano; con mate en mano, el personaje se presentaba junto a Moderato, quien le preguntaba: "Papi, ¿Si secuestro a la maestra, podemos intervenir la escuela? ${ }^{51}$.

Como se ha dejado ver, Tendencio retrató el avance del Estado de excepción, el distanciamiento respecto de Perón y el enfrentamiento con la derecha peronista. En efecto, el protagonismo de la tira cómica y la irritación que causó en muchos actores del peronismo fue tal, que llegó a estar representada en la revista paradigmática de la derecha peronista: en noviembre del 73 comenzó a publicarse "El Caudillo", dirigida por Felipe Romeo y

\footnotetext{
${ }^{47}$ Pacheco, Julieta, “Acerca del programa de la organización Montoneros: ¿reformistas o revolucionarios?”, en: Trabajo y Sociedad $\mathrm{N}^{\circ}$ 23, Santiago del Estero, 2014, P.: 254.

${ }^{48}$ Militancia Peronista para la Liberación $N^{\circ} 27$, P.: 7

${ }^{49}$ Militancia Peronista para la Liberación $\mathrm{N}^{\circ}$ 29, 29 de Diciembre de 1973, tapa.

${ }^{50}$ Franco, Marina. op. cit.

${ }^{51}$ Militancia Peronista para la Liberación No 36, 7 de Marzo de 1974, P.: 7
} 
financiada por López Rega. Éste semanario se inspiró en la tira cómica de $M P L$ y creó una propia denominada "Ortodoxio", que tuvo por objeto satirizar a Tendencio.

\section{Ortodoxio: Persecuciones y amenazas en papel y tinta}

El Caudillo de la Tercera Posición fue una revista vinculada a la derecha peronista y dirigida por Romeo -miembro de la Guardia Restauradora Nacionalista que se escindió por derecha de la organización nacionalista Tacuara. El semanario aglutinó a las organizaciones más importantes del sector: la Alianza Libertadora Nacionalista (ALN), el Comando de Organización ( $\mathrm{C}$ de $\mathrm{O}$ ), la Concentración Nacional Universitaria (CNU), la Juventud Peronista de la República Argentina (JPRA) y la Juventud Sindical Peronista, quienes encontraron en ella su órgano natural de expresión ${ }^{52}$.

EC circuló por primera vez el 16 de noviembre de 1973, a pocos días de que hiciera su aparición pública la organización para-estatal Triple A; su objeto era representar la voz de la derecha peronista y contrarrestar la línea editorial de las revistas vinculadas a "la Tendencia" como El Descamisado o $M P L^{53}$. La revista evidenciaba el conocimiento de las posiciones de la izquierda peronista y la lectura de sus materiales y órganos de difusión: el estilo de EC imitaba al de El Descamisado y la línea editorial discutía -en reiteradas oportunidades- con las posiciones de MPL. De hecho Ortodoxio es, en sí mismo, una respuesta directa a las apreciaciones de Tendencio.

La tira cómica de derecha apareció por primera vez en el número 4 de $E C$, publicado en diciembre del 73. El número titulaba "Perón siempre triunfa" y la editorial firmada por Romeo- apuntaba: "Perón + Isabel = Orden; Marxismo / Capitalismo = Caos". Hacia el final de esta edición se presentaba Ortodoxio, un personaje con bigotes, cabeza en forma de $\mathrm{P}$ y escote en forma de $\mathrm{V}$ que simbolizaba la insignia del peronismo. Con un ejemplar de EC en la mano derecha, Ortodoxio increpaba a Tendencio exclamando: "Hacete a un lado, Tendencio, mirá que desde el próximo viernes el que manda acá soy YO" ${ }^{24}$ [Fig. 4] La imitación del personaje de MPL era muy similar pero introducía una distinción: el que aparecía en las páginas de EC llevaba una enorme "T" en el pecho. En el número posterior, la tira continuaba con el mismo tema y presentaba a Tendencio tirado en el piso, aterrorizado. Ortodoxio lo enfrentaba desafiante preguntándole qué sucedía hasta que, en el último recuadro, el personaje de $M P L$ exclamaba que tenía "cagazo"

Las referencias a $M P L$ eran permanentes; $E C$ retomaba explícita e implícitamente temas, debates y discusiones expresos en el semanario de izquierda. En el número 6, la revista de la derecha retomaba la tira cómica de $M P L$ publicada en el número $22-$ del 8 de Noviembre- en dónde Tendencio aparecía sin sus pies, diciéndole a Moderato: "Lo

\footnotetext{
52 Besoky, Juan Luis. La derecha peronista. Prácticas y representaciones (1943-1976). Tesis doctoral, Universidad Nacional de La Plata, 2016

${ }^{53}$ Besoky, Juan Luis. "Tendencio y Ortodoxio. El enfrentamiento entre la derecha e izquierda peronista a través del humor gráfico”. Ponencia: en Congreso de Historieta y Humor Gráfico, Buenos Aires, 2014.

${ }^{54}$ El Caudillo de la Tercera Posición N ${ }^{\circ}$ 4, 7 de Diciembre de 1973, P: 23, En: www.ruinasdigitales.com

${ }^{55}$ En lunfardo, temor / En: El Caudillo de la Tercera Posición N 5, 14 de diciembre de 1973 P.: 23
} 
importante es no sacar los pies del plato" mientras a su lado figuraba un plato en dónde se apoyaban sus pies mutilados ${ }^{56}$. MPL volvía sobre una frase del discurso que Perón dio frente a los gobernadores el pasado 2 de Agosto; allí el líder había alertado que el accionar de la militancia revolucionaria debía realizarse "dentro de la ley. Cuidado con sacar los pies del plato, porque entonces tendremos el derecho a darles con todo" ${ }^{~} 57$. La advertencia también aludía a la necesidad de no apartarse de su doctrina y directivas y expresaba el debate que estaba sucediéndose dentro de "la Tendencia" entre las posiciones movimientistas - que defendían la verticalidad respecto de las órdenes de Perón- y aquellos que (como $M P L$ ) apuntaban la necesidad de afianzar posiciones revolucionarias, respondan o no a las directivas del líder. En alusión a esta viñeta, el número 6 de $E C$ presentaba a Ortodoxio preguntando: “¿Así que estás ensayando para poner los pies dentro del plato?; al respecto Tendencio retrucaba: “Cómo adivinaste?” y Ortodoxio remataba "Porque te quedó un fideo en el dedo gordo" 58 .

En esta línea de diálogo, EC número 7 -publicado el 28 de Diciembre- retomaba las posiciones del número 27 de $M P L$, dónde la revista apuntaba como un recuerdo lejano la posibilidad de pensar "la patria socialista". En respuesta a ello, Ortodoxio aparecía junto a Tendencio que se encontraba dentro de un pozo, dándose martillazos en la cabeza. En la primera viñeta Ortodoxio le preguntaba: “eh, che ¿Qué haces?” y Tendencio respondía: "profundización doctrinaria". En el último recuadro, el personaje de $M P L$ dejaba ver las herramientas que estaba utilizando: una hoz y un martillo (símbolos del comunismo). Ortodoxio le decía: "No vas a ir muy lejos. Esas herramientas no sirven para este trabajo",59. El personaje de la derecha se presentaba como portador del significado de "ser peronista" y encarnaba las acusaciones de infiltración comunista que, desde la cúpula del Movimiento, se realizaban sobre los sectores de izquierda.

El humor gráfico fue utilizado por la revista de Romeo para representar la disputa entre la derecha y la izquierda encarnando amenazas y persecuciones. Es interesante sugerir que $E C$ discutió, fundamentalmente, con las posiciones alternativistas tanto por su cercanía con la izquierda marxista como por el desafío revolucionario que suponían. En este punto, tanto Montoneros - JP como sus órganos de difusión quedaron alineados a estas posiciones, independientemente de las diferencias y debates que las separaban. Como ejemplifica Besoky, la referencia a la Alternativa Independiente se tornó explícita y en el número 14, Tendencio figuraba atado a un bombo peronista mientras era brutalmente atacado por Ortodoxio mientras, a su costado, la figura de un diablito acotaba: "la salida independiente, viste" 60 [Fig. 5]

A su vez, el número 23 representaba aquella homogeneización que la derecha realizaba sobre la izquierda peronista: el personaje de $M P L$ aparecía sosteniendo un cartel

\footnotetext{
${ }^{56}$ Militancia Peronista para la Liberación N 22, 8 de Noviembre de 1973, P.: 6.

${ }^{57}$ Perón, Juan Domingo. "Discurso a los gobernadores", Ibíd.

${ }^{58}$ El Caudillo de la Tercera Posición $N^{\circ}$ 6, 21 de Diciembre de 1973, P.: 23

${ }^{59}$ El Caudillo de la Tercera Posición N 7, 28 de diciembre de 1973, P.: 23

${ }^{60}$ El Caudillo de la Tercera Posición N 14, 15 de Febrero de 1974, P.: 23.
} 
con la leyenda "JUP - Montos" e interrogado por Ortodoxio -quien lo instaba a salir del espacio peronista- respondía:

Estoy acá para apoyarlo a Perón contra el imperialismo yanqui y sus lacayos fascistas. (...) La orden fue terminante: primero debemos apoyar, luego presionar, después condicionar y si es preciso inmovilizar, apretar y reventar la gestión del gobierno popular. La 'salida alternativa'... ¿viste ? $^{61}$

La tira cómica publicada por $E C$ se convertía en una herramienta más para canalizar - de manera pública y tamizada- las amenazas que las organizaciones de la derecha realizaban en contra de la militancia revolucionaria. El diálogo fue uni-lateral, dado que la revista de Ortega Peña y Duhalde nunca respondió a las agresiones de Ortodoxio. Sin embargo, la violencia de las imágenes, el carácter explícito de las amenazas -que no sólo interpelaban al grupo político-editorial sino a la militancia en general-, etc. eran expresión simbólica del terrorismo ideológico perpetrado por la revista financiada por López Rega.

Es interesante resaltar que la apropiación de Tendencio para increparlo y ridiculizarlo expresa varias cuestiones: primero permite pensar en la importancia que había logrado la tira de $M P L$, tanto por la influencia como por la difusión que había adquirido el personaje. En segundo lugar, la utilización del humor gráfico para representar la persecución política da cuenta de la naturalización en torno de la violencia en espiral ascendente; finalmente (pero en íntima vinculación) afirma el carácter "transideológico de la ironía" 62 que aquí, lejos de ser subversiva, se afirmó guardiana del statu quo.

Más allá de que la derecha peronista percibiera como iguales -es decir, enemigos infiltrados- a los diferentes actores de "la Tendencia", ésta estuvo atravesada por tensiones y diferencias. El debate con las organizaciones movimientistas atravesó el planteo de MPL, subyaciendo a las caracterizaciones que la revista realizó sobre las organizaciones hegemónicas del peronismo revolucionario (Montoneros y JP). En lo que sigue, analizaremos cómo Tendencio representó estas discusiones.

\section{Las andanzas de Tendencio en "la Tendencia": el debate con Montoneros y Juventud Peronista (JP)}

La revista $M P L$ no solo fue un medio político-cultural; fue también un actor político que sentó posiciones y realizó apuestas dentro de "la Tendencia" alineándose con los sectores alternativistas. Estas posturas llevaron a que el análisis del proceso político se alejara de las interpretaciones movimientistas que, encarnadas por Montoneros y JP, se tornaron hegemónicas dentro de la izquierda peronista.

Si bien en un primer momento la revista compartió con los demás sectores del peronismo revolucionario las expectativas que despertaba la gestión de Cámpora, las

\footnotetext{
${ }^{61}$ El Caudillo de la Tercera Posición $\mathrm{N}^{\circ} 23$ citado en: Besoky, J.L, Ibíd., P.: 9.
}

${ }^{62}$ Schoentjes, Pierre, op. cit., p.: 54. 
diferencias comenzaron a ser notorias a partir de su renuncia. Alejándose de las interpretaciones de Montoneros y JP que lo analizaban como un gesto similar al renunciamiento de Eva Perón y apuntaban que "debía hacerlo porque esa era la condición que puso para aceptar la candidatura [aunque] los aspirantes a herederos quisieron hacerlo aparecer como producto de sus maniobras"63; MPL denunciaba un "golpe palaciego" acercándose más a la lectura del ERP -que lo analizaba como un "auto-golpe contrarrevolucionario". Si bien el semanario apuntaba responsables en la derecha del Movimiento, la burocracia sindical y sectores aliados en las FFAA, introducía una crítica implícita a Montoneros-JP aduciendo que "el golpe de Lastiri" se había producido en parte, porque "quienes tenían desde el 25 de Mayo la responsabilidad de marcar la línea política revolucionaria del peronismo [dejaron avanzar a] la burocracia traidora (...) abandonando sus consignas en aras de una mal entendida verticalidad" ${ }^{64}$. La revista actualizaba el debate entre movimientistas y alternativistas que venía cruzando a la izquierda peronista y cobraba relevancia ante la realidad del Movimiento y la conflictiva experiencia de su tercer gobierno.

La aparición de Tendencio fue un elemento clave en el distanciamiento que el grupo político encarnó respecto de Montoneros y JP. Acido y crítico, el personaje había llegado para quedarse y sólo a través del nombre, ironizaba sobre las posiciones hegemónicas de la Tendencia Revolucionaria. El recurso del humor permitía que la revista diga lo indecible, de una manera muy particular. Despersonalizando la crítica -ya que era Tendencio quien la realizaba- $M P L$ podía ser dura con las organizaciones más importantes del peronismo revolucionario, si consideraba que éstas estaban tomando un camino erróneo.

Si bien las primeras viñetas tuvieron por interlocutores al gobierno y a los sectores de la derecha peronista, la crítica a Montoneros y JP no tardo en llegar y tuvo por eje la participación de ambas organizaciones en el acto del 31 de Agosto, convocado por la CGT y organizado para apoyar la candidatura de Perón y la fórmula junto a Isabelita.

Las organizaciones Montoneros y JP habían resuelto aceptar la convocatoria y tras el acto, El Descamisado resumía los hechos como "un triunfo: el de Perón; una crisis: la burocracia; una realidad: el trasvasamiento" destacando que la JP había movilizado el 60 \% de quienes asistieron a "saludar a Perón". Más aún, el editorial consideraba que Perón no había vuelto el 20 de Junio sino el 31 de Agosto "porque la realidad del regreso está dada por el encuentro físico" ${ }^{65}$. La revista reivindicaba la decisión de concurrir a través del argumento político movimientista que postulaba la necesidad de no marginarse del Movimiento.

Lejos de estos posicionamientos, MPL asentaba fuertes críticas. En su editorial número 13 del 6 de Septiembre, la revista apuntaba que la concentración había implicado un aval para la burocracia, alineando a la JP con su proyecto político general y motivando una sonrisa de triunfo en Lorenzo Miguel y Rucci ${ }^{66}$. En esta línea, Tendencio irrumpía en la

\footnotetext{
${ }^{63}$ El Descamisado $N^{\circ}$ 9, 17 de Julio de 1973. En: www.eltopoblindado.com

${ }^{64}$ Militancia Peronista para la Liberación $\mathrm{N}^{\circ} 6, \mathrm{p} .: 3$.

${ }^{65}$ El Descamisado $N^{\circ} 16,4$ de Septiembre de 1973, p: 4

${ }^{66}$ Militancia Peronista para la Liberación $N^{\circ} 13,6$ de Septiembre de 1973, p.: 3.
} 
página 9 sosteniendo hacia abajo una cuerda de dónde colgaban diversos carteles con consignas de la militancia revolucionaria: "Patria Socialista", "Trelew - Ezeiza", "Guerra Popular", "Evita" mientras el personaje exclamaba: "¡No dirán que no bajo la línea!"67 [Fig. 6]; provocativamente, $M P L$ dejaba entrever que una de las organizaciones más importantes de "la Tendencia" había echado por tierra las reivindicaciones de la militancia revolucionaria con la excusa de no auto-excluirse del Movimiento; el semanario apuntaba explícitamente que el acto había resultado en un triunfo para la burocracia: no se había logrado cambiar ni su forma ni su contenido, Perón se había presentado junto a "lo peor del Movimiento" y "la prensa cipaya" había elogiado la "buena conducta" de la JP ${ }^{68}$. Más adelante, $M P L$ volvía apelar a la ironía para cuestionar este tipo de posiciones a través del hijo de Tendencio, cuyo nombre también deslizaba una crítica a Montoneros y JP: la elección del mote "Moderato" refleja la ambigüedad del recurso retórico de la ironía, que permite crear controversia a través de la dificultad que acecha la interpretación. En este punto, aquella nominación puede leerse como el planteo del vínculo político entre "la Tendencia" -hegemonizada por aquellas- y la moderación, que MPL buscaba denunciar. La revista insistía en que el movimientismo montonero llevaba a que "la Tendencia" recayera en posiciones vacilantes que terminaban retrasando el proceso revolucionario. En éste punto, el posicionamiento de Montoneros-JP respecto de hechos clave como la Ley de Asociaciones Profesionales ${ }^{69}$ o el discurso que Perón pronunció en la CGT el 13 de Noviembre, fueron ironizados por Tendencio con ésta misma línea.

Respecto del proyecto de ley que modificaba la estructura sindical -implicando entre otras cosas, la intervención de los sindicatos menores y el derecho a revisar las decisiones de las comisiones de fábrica- la JTP apoyó inicialmente algunas de sus cláusulas, aludiendo la importancia de construir una CGT poderosa, fuerte y unificada que fortaleciera al movimiento obrero organizado ${ }^{70}$. La posición de $M P L$ fue de rechazo absoluto: cuando los diputados de la JP estuvieron a punto de votar a favor de la nueva ley, presionados por el Consejo Superior del Movimiento, Tendencio aparecía colgado con una soga al cuello mientras Moderato le preguntaba atónito: "Papi, ¿Así se practica verticalidad al Consejo?" "71. La tira cómica sugería que la decisión política de votar a favor de la Ley de Asociaciones Profesionales era un "suicidio político". En ésta línea pero de manera explícita, la sección "Semana Política" interpelaba a los diputados explícitamente,

\footnotetext{
${ }^{67}$ Militancia Peronista para la Liberación $\mathrm{N}^{\circ} 13$, p.: 9.

${ }^{68}$ Militancia Peronista para la Liberación $\mathrm{N}^{\circ} 13$, p.: 6.

69 Tanto las modificaciones a la Ley de Asociaciones Profesionales como la Ley de Prescindibilidad significaron dispositivos legales de "diciplinamiento" propulsados por Perón quien pretendió proteger a la dirigencia sindical a partir de este tipo de medidas. [Schenider, Alejandro. "Cuando se hizo tronar el escarmiento. La política laboral de Juan D. Perón para disciplinar el movimiento obrero" En Ghigliani, P y Schneider, A: Sobre trabajadores y el mundo del trabajo en Argentina, Buenos Aires, Imago mundi, 2015, p.:129]

${ }^{70}$ El Descamisado $N^{\circ} 25,6$ de Septiembre de 1973

${ }^{71}$ Militancia Peronista para la Liberación $\mathrm{N}^{\circ} 25,29$ de Noviembre de 1973, p.: 7
} 
apuntando: "Se equivocan. Perón persuade. Solo la clase obrera y el pueblo peronista mandan". 72

El 13 de Noviembre de 1973, Perón dio su tercer discurso en la CGT. En esta oportunidad, el líder ahondó en la necesidad de profundizar la formación doctrinaria del peronismo y volvió a arremeter contra la "infiltración" dentro del Movimiento, que a sus ojos pretendía destruirlo. En la interpretación que $M P L$ realizó sobre este discurso, las críticas al movimientismo se profundizaron. A esta altura, $M P L$ enfrentaba a Perón y denunciaba que había traído del exilio un pre-concebido plan político; a su vez afirmaban que el día en que la tribuna del líder deje de ser la CGT para ser la Plaza de Mayo o que a su lado dejen de estar Llambí, López Rega, Otero, etc. comenzaría la verdadera reconstrucción nacional ${ }^{73}$. La posición de Montoneros y JP fue diferente y si bien deslizaban críticas, el editorial de El Descamisado terminaba afirmando que "quien conduce es Perón y quienes cuestionan esto, están fuera del Movimiento" ${ }^{74}$. Ironizando sobre estas posiciones, Tendencio aparecía colgado de uno de los lados de la viñeta y dentro del recuadro se leía el siguiente aviso: "Esta semana Tendencio quedó fuera del marco por un mal encuadramiento de conjunto. Prometemos que en el próximo número será un ejemplo por lo centrado" ${ }^{75}$. Pero lejos de esta promesa, el número siguiente profundizó las críticas y cuestionó el intento de Montoneros-JP de resguardar espacios de poder dentro de un Movimiento que expresaba la política de la burocracia. En el editorial número 24, la revista titulaba "Mimetismo trágico" y afirmaba:

Desde un tiempo a esta parte estamos asistiendo al forzado mimetismo que importantes sectores de la Tendencia intentan con la repudiada y cuestionada dirección político-sindical del Movimiento, con el fin de prolongar una definición inevitable. En este número, Militancia proporciona nuevos análisis sobre las limitaciones y peligros de la llamada "política de conjunto" así como el carácter peligroso de la defensa del "espacio político logrado" (...) esta revista no dejará de señalar lo que estima una política equivocada y autodestructiva ${ }^{76}$.

Según $M P L$, éstos sectores se acercaban a la burocracia, evitando asumir una política propia que "si expresa a la clase obrera y al pueblo peronista, implica tomar distancias con el proyecto político gubernamental"; en esta línea sostenían: "como no hay terceros caminos ese necesario enfrentamiento llevaría a optar por la lucha superestructural de aparatos o por la vuelta a las bases"77. Reflejando la posición alternativista y cuestionando las vacilaciones de Montoneros y JP, Tendencio aparecía en la página 9 del lado derecho de la página, encuadrado en una viñeta pequeña que apenas dejaba espacio

\footnotetext{
${ }^{72}$ Militancia Peronista para la Liberación $\mathrm{N}^{\circ} 25$, p.: 5

${ }^{73}$ Militancia Peronista para la Liberación $\mathrm{N}^{\circ} 23,15$ de Noviembre de 1973, p.: 3

${ }^{74}$ El Descamisado 26, 13 de Noviembre de 1973.

${ }^{75}$ Militancia Peronista para la Liberación $\mathrm{N}^{\circ} 23$, p.: 7

${ }^{76}$ Militancia Peronista para la Liberación 24, 22 de Noviembre de 1973, 3

${ }^{77}$ Militancia Peronista para la Liberación $\mathrm{N}^{\circ} 24$, p.: 3
} 
para su silueta. Allí se lo veía sin el mate, elemento que aparecía alejado, del lado izquierdo y junto a una pequeña nota que informaba sobre un congreso del Peronismo de Base. Ajustado en su pequeño recuadro, Tendencio afirmaba: "Lo importante es defender el espacio político"78 [Fig. 7]. Esta viñeta resulta especialmente interesante por varios motivos: en primer lugar, sintetiza con claridad las críticas que la revista venía realizando en torno a "la política de conjunto"; en segundo lugar, el detalle del mate (símbolo popular) fuera de la viñeta, daba cuenta de los riesgos que suponía continuar afirmando posiciones movimientistas: el alejamiento de las bases. Finalmente -pero en íntima vinculación- el hecho de que ese mate se ubicara junto a un recuadro con información sobre el PB era un guiño directo a esta organización y a la política alternativista que sostenían.

Otro de los debates clave que enfrentó a MPL con Montoneros y JP fue la posición de ambas organizaciones frente a algunos sectores de las Fuerzas Armadas. En términos generales, el debate tomó estado público con el discurso que el Gral. Carcagno dictó el 5 de Septiembre en la Conferencia de Ejércitos Americanos. Con tonalidades filo-progresistas, el comandante en jefe de las FFAA reconocía como principios básicos e inalienables la no intervención, la autodeterminación de los pueblos y el respeto a las individualidades de cada país. Este posicionamiento resultaba antitético con las doctrinas norteamericanas hacia América Latina y el mundo ${ }^{79}$. Las repercusiones de su discurso se aunaban con las expectativas que despertaba la presidencia del General Torrijos en Panamá y abría el debate acerca de si los militares podían ser considerados como aliados en la lucha antiimperialista. MPL retomaba esta discusión el 20 de setiembre, con el golpe en Chile resonando sus análisis. En la "Sección Polémica" la revista sintetizaba el debate en torno a si era posible "que los militares se hayan vuelto peronistas y antiimperialistas (...) teniendo en cuanta las declaraciones de Carcagno en Caracas". La sección apuntaba que la respuesta debía remitirse a "la historia personal de Carcagno" y criticaba a los sectores que, desde el espectro revolucionario peronista, se acercaban al Comandante en Jefe de las FFAA. La revista señalaba: "sin perjuicio de que existan, y existen, oficiales revolucionarios (...) las FFAA no son un lugar donde se den todas las contradicciones de la sociedad, sino que en ellas se asumen, por el contrario y claramente, los intereses de la burguesía" ${ }^{\prime 20}$.

Con definiciones que la acercaban a la izquierda marxista y se referenciaban en $\mathrm{J}$. W. Cooke, la revista afirmaba su clasismo y contradecía a Montoneros-JP que desde $E l$ Descamisado, aplaudía el discurso de Carcagno y afirmaba que también en las armas penetraban las mismas contradicciones que en la sociedad ${ }^{81}$. Esta posición fue ironizada por Tendencio quien en este mismo número, aparecía señalando a un gorila con uniforme

\footnotetext{
${ }_{78}^{78}$ Militancia Peronista para la Liberación $\mathrm{N}^{\circ} 24$, p.: 9

79 Caviasca, Guillermo. "La actuación del General Jorge Carcagno en la X Conferencia de Ejércitos Americanos en Caracas. Significado, antecedentes y debates", En: Cuaderno de trabajo N 5, Buenos Aires, Ministerio de Defensa, 2015.

${ }^{80}$ Todas las citas del párrafo pertenecen a: Militancia Peronista para la Liberación $\mathrm{N}^{\circ}$ 15, 20 de Septiembre de 1973, p: 8

${ }^{81}$ El Descamisado $\mathrm{N}^{\circ} 17,11$ de Septiembre de 1973.
} 
militar mientras exclamaba: “¡Como ha cambiado!, ¡Usted no es el mismo gorila que antes!".

La crítica de $M P L$ tendió a endurecerse cuando en Octubre, la JP puso en marcha "el Operativo Dorrego" en conjunto con el Ejército, a los fines de colaborar con barrios de Buenos Aires, afectados por las inundaciones. En el número 19, publicado el 18 de Octubre, la revista afirmaba: "el hecho de referencia no aporta sino oscuridad al proceso político, porque el ejército represor (...) no ha cambiado en su esencia por el tono de un discurso" 82 [en referencia al pronunciado por Carcagno]. Endureciendo el análisis, MPL afirmaba que el Ejército no devenía en "ejército del pueblo" por una expresión de deseo de de la JP que "en una de esas, un día descubre que en vez de haber trabajado por la Argentina Socialista, estuvo poniendo sus esfuerzos en la Argentina potencia, pero potencia para los usufructuarios del esfuerzo obrero" ${ }^{~}$. En este número, Tendencio aparecía enyesado y con un ojo morado, mientras Moderato le preguntaba atónito: “¿Otra vez te encontraste con los aliados tácticos?"84. La crítica al Operativo Dorrego aparecerá de manera explícita en la viñeta del número siguiente, con un Tendencio a punto de ser fusilado: atado de pies y manos y con una venda en los ojos, el personaje es apuntado por escopetas del Ejército, mientras pregunta: “¿Está seguro Coronel que así es el Operativo Dorrego?" ${ }^{85}$ [Fig. 8]. Esta será una de las pocas críticas que acudirá a la sátira política para referir a la JP: la revista la dejaba en ridículo, aludiendo a su falta de visión política y revolucionaria.

La discusión en torno al rol de las FFAA se retomó en diciembre cuando el gobierno de Perón decida pasar a retiro al General Carcago. Allí, la revista editorializaba "Adiós a las armas" apuntando que

Los sueños peruanistas de los que creen factible encontrar la revolución en un recodo cuartelero ha sufrido un grave deterioro. Aquellos que pudieron olvidar el papel de guardaespaldas del fascismo colonial de las FFAA latinoamericanas, encandilados por algún discurso, por un operativo conjunto [refieren al Operativo Dorrego] o por conversaciones de madrugada [en referencia al contacto que Carcagno había tenido con los líderes Montoneros ${ }^{86}$ ] vuelven a descubrir que no hay hombres ni fuerzas del campo enemigo computables con un proceso revolucionario ${ }^{87}$

\footnotetext{
${ }^{82}$ Militancia Peronista para la Liberación $\mathrm{N}^{\circ}$ 19, 18 de Octubre de 1973, p.: 14

${ }^{83}$ Militancia Peronista para la Liberación $\mathrm{N}^{\circ} 19$, p.: 14

${ }^{84}$ Militancia Peronista para la Liberación $\mathrm{N}^{\circ} 19$, p.: 7

${ }^{85}$ Militancia Peronista para la Liberación $N^{\circ} 20,25$ de Octubre de 1973, p.: 9

${ }^{86}$ Caviasca cita el fragmento de una entrevista con Roberto Perdía dónde el dirigente Montonero se expresa sobre la relación con Carcagno: "nosotros teníamos las relaciones desde antes. Yo diría que el viaje y la posición es una parte de esta política. No es una casualidad, ni el viaje ni la posición. Todas estas campañas fueron, todas, un solo paquete. La relación con los militares peruanos que eran viejos amigos nuestros. También formaba parte de todo esto" [Testimonio de Roberto Perdía, en entrevista con Guillermo Caviasca, Ibíd., p.: 13]

${ }^{87}$ Militancia Peronista para la Liberación $N^{\circ} 28,20$ de diciembre de 1973, p.:3
} 
En el contexto de la escalada represiva de Enero del 74’, tras la reforma al Código Penal, la renuncia de Bidegain y la designación de los comisarios Villar y Margaride (vinculados al ejercicio represivo) como Subjefe de la Policía Federal y superintendente de Seguridad Federal respectivamente, Tendencio arremetía contra las posiciones de "la Tendencia" que continuaban apelando al liderazgo de Perón, vinculándolo con los procesos revolucionarios latinoamericanos como el de Torrijos en Panamá.

En el número 31, el personaje ironizaba sobre una nota publicada en $E l$ Descamisado, titulada "Torrijos, un General Peronista", en dónde la revista montonera vinculaba el proceso panameño con Perón y apuntaba que la JP "coherente con el pensamiento de su líder" trabajaba por la integración latinoamericana con una propuesta clara y concisa $^{88}$. La crítica de MPL estuvo encarnada por Moderato quien interrogaba a Tendencio: "Papi, ¿a Torrijos también hay que hacerle creer lo de Argentina Potencia?" 89.

El grupo político-editorial insistió desde épocas tempranas en la necesidad de asumir las contradicciones internas del peronismo, su lectura en términos clasistas y la consecuente decisión de conformar una alternativa política para la clase obrera y el pueblo peronista que tenga su correlato en una estrategia frentista, puente entre las organizaciones revolucionarias peronistas y aquellas de la izquierda marxista. Las críticas y debates al movimientismo tendrán estas apuestas de trasfondo, sin dejar de interpelar a Montoneros y JP -en tanto organizaciones hegemónicas de la Tendencia- como necesarias protagonistas. Esta necesidad explica porqué el humor gráfico de Tendencio, cada vez que se refirió a ellas, recurrió a la ironía evitando recaer en la sátira política, instrumento que tiende a ridiculizar y rebajar a quien es objeto de burla.

\section{Algunas conclusiones}

Este artículo se ha propuesto analizar las disputas dentro del peronismo durante los años 1973-74 y las transformaciones de la identidad política peronista de la revista MPL, a través de sus representaciones en el humor gráfico protagonizado por Tendencio. Con este objetivo, se ha buscado demostrar cómo MPL simbolizó las tensiones que atravesaron a la izquierda peronista en su disputa con los sectores de derecha, la experiencia del peronismo gobernante y el propio Perón por un lado y por el otro, dentro de la auto-denominada Tendencia Revolucionaria, los debates entre las posiciones movimientistas sostenidas por Montoneros y JP y aquellos sectores que afirmaban la necesidad de construir una "Alternativa Independiente" al Movimiento. El grupo político-editorial de $M P L$ re-definió las fronteras de su identidad política, haciendo dialogar al peronismo con un marxismo situado en el lugar de la teoría. Ante la adversidad del contexto, la derechización del gobierno y el distanciamiento cada vez más profundo respecto de Perón, la revista reforzó las lentes marxistas articuladas en su identidad política, acentuando el clasismo en sus planteos y apostando por una estrategia frentista que interpelaba dos procesos opuestos pero

\footnotetext{
${ }^{88}$ El Descamisado $N^{\circ} 36,22$ de Enero de 1974, p.: 7.

${ }^{89}$ Militancia Peronista para la Liberación $N^{\circ} 31,17$ de Enero de 1974, p.: 7.
} 
iguales: la peronización de la izquierda y la izquierdización del peronismo (en sentido marxista). Estas posiciones la llevaron a alinearse explícitamente con la corriente alternativista que, con similares características, venía desarrollándose desde el 71' dentro de la Tendencia Revolucionaria Peronista.

Las transformaciones político-ideológicas del grupo editorial se expresaron en la revista y el humor gráfico no se mantuvo al margen. Por el contrario -como se ha buscado demostrar- la tira cómica simbolizó de particular manera estas rupturas y disputas. Si bien MPL fue un semanario dedicado al análisis político, Tendencio adquirió sorpresiva centralidad. Como vimos, el personaje fue un hallazgo casual que se transformó en un ícono de $M P L$ repercutiendo con sus críticas tanto sobre los sectores de derecha como de la izquierda peronista. En el primer caso, la influencia fue tal que la revista paradigmática $E l$ Caudillo retomó al personaje, lo incorporó en una tira propia y canalizó a través suyo las amenazas, persecuciones y tensiones que se estaban dando en la realidad. Para el caso de la izquierda peronista, Tendencio resultaba particularmente molesto. Si bien no se registran respuestas de Montoneros y JP en sus órganos de difusión, testimonios posteriores aseguran que la dirección montonera prohibía la lectura de $M P L$ por considerar que sus críticas y su confrontación con Perón eran "un problema semanal" caracteriza a Tendencio como "una herramienta para poder transmitir cosas que desde otro modo hubieran sido mucho más difíciles (...) a la vez fue altamente irritativo... creo que un artículo que dijera lo mismo irritaba menos que una caricatura de Tendencio" $"$.

De esta forma el personaje encarnó la existencia de una "autor colectivo" que se confundió con una manera de hacer grupal que representaba a (y era representada por) determinados actores dentro del peronismo revolucionario. El humor gráfico sirvió de puente entre Tendencio y el decir del grupo político-editorial, encarnando las apuestas políticas de MPL sea dentro de la Tendencia -en el debate con sus sectores movimientistaso fuera de ella, en la disputa por los sentidos del peronismo.

Aquí es necesario aclarar que los ejes a partir de los cuales analizamos al personaje solo pueden separarse con fines analíticos. Las críticas al proceso político, a Perón y al peronismo estuvieron íntimamente vinculadas al debate con el movimientismo y en muchos casos, el chiste de Tendencio encarnaba una crítica dual, susceptible de ser interpretada en ambos sentidos. En segundo lugar, no se han registrado antecedentes de tiras cómicas en revistas coetáneas de análisis político -excepto El Caudillo, que replicó a la sección de MPL. La centralidad que Tendencio adquirió es indicativa de la encarnación que el personaje logró de los debates más importantes dentro del peronismo y de su perspicacia y agudeza en el análisis político. Finalmente, la apelación al humor no fue privativa de la tira cómica sino que fue un recurso presente en otras secciones de la revista y en el epígrafe de las fotografías. Su análisis quedará pendiente para próximos trabajos.

\footnotetext{
${ }^{90}$ Ver testimonios de Duhalde, Eduardo Luis y Perdía, Roberto en: Celecia, Felipe y Waisberg, Pablo. La ley y las armas. Biografía de Rodolfo Ortega Peña, Buenos Aires, Editorial Aguilar, 2007, pp.: 264 y 250 respectivamente.

${ }^{91}$ Duhalde, Marcelo en entrevista con la autora, Buenos Aires, 2014.
} 


\section{Bibliografía}

Altamirano, Carlos. Peronismo y cultura de izquierda, Buenos Aires: Editorial Silgo XXI, 2001

Besoky Juan Luis, "Tendencio y Ortodoxio, el enfrentamiento entre la derecha y la izquierda peronista a través del humor gráfico". En: Congreso de Historieta y humor gráfico, 2014.

------- La derecha peronista. Prácticas y representaciones (1943-1976). Tesis doctoral, Universidad Nacional de La Plata, 2016

Bozza, Alberto. "La resignificación revolucionaria del peronismo y sus protagonistas durante la etapa de la proscripción”, en: Tortti, María Cristina (dir), Chama, Mauricio y

Celentano, Adrián (co-dir) La Nueza Izquierda Argentina. Socialismo, Peronismo y Revolución, 1955-1976, Rosario, Ediciones Prohistoria, 2014

Burkart, Mara: "De la libertad al infierno, La revista Satiricón (1972-1976)", En: Gené, Marcela y Malosetti, Laura (comp.): Atrapados por la imagen. Arte y política en la cultura impresa argentina, Buenos Aires, Edhasa, 2013

“Caricaturas de Perón en Satiricón (1972-1974)", En: Papeles de Trabajo, N 7, Buenos Aires, 2011. Pp.: 44-73;

"Risa, sexo y censura política en la Argentina de los años setenta. La revista Satiricón (19721976)”, en: III Congreso Internacional do Núcleo de Estudos das Américas, Río De Janeiro, 2012.

Caviasca, Guillermo. "La actuación del General Jorge Carcagno en la X Conferencia de Ejércitos Americanos en Caracas. Significado, antecedentes y debates". En: Cuaderno de trabajo N 5, Buenos Aires, Ministerio de Defensa, 2015.

Celecia, Felipe y Waisberg, Pablo, La Ley y las armas. Biografía de Rodolfo Ortega Peña, Buenos Aires, Ediciones Aguilar, 2007.

De Riz, Liliana. La política en suspenso, 1966/1976, Buenos Aires, Paidós, 2000

Franco, Marina. Un enemigo para la Nación. Orden interno, violencia y “subversión”, 1973-1976, Buenos Aires, Fondo de Cultura Económica, 2012.

Gilman, Claudia. Entre la pluma y el fusil, debates y dilemas del escritor revolucionario en América Latina, Buenos Aires, Editorial Siglo XXI, 2012.

González Canosa, Mora. "Las Organizaciones Armadas Peronistas (OAP): un análisis comparativo de los (re) posicionamientos de las FAR", en: Tortti, María Cristina (dir), Chama Mauricio y Celentano Adrián (co-dir) La Nueza Izquierda Argentina. Socialismo, Peronismo y Revolución, 1955-1976. Rosario, Ediciones Prohistoria, 2014 
"Políticas de construcción del peronismo. El discurso de las FAR en los albores de la década del setenta en Argentina" En: Tempo \& Argumento Vol. 7, № 14, Florianópolis, 2015.

Grassi, Ricardo, El Descamisado, periodismo sin aliento, Buenos Aires, Editorial Sudamericana, f2015

James, Daniel, Resistencia e integración. El peronismo y la clase trabajadora argentina 1946-1976, Buenos Aires: Editorial Siglo XXI, 2010.

Lanusse, Lucas. Montoneros. El mito de sus 12 fundadores, Buenos Aires, Editorial Vergara, 2005

Lenci, María Laura. "Radicalización de los católicos en Argentina. Peronismo, cristianismo y revolución (1966-1971)”, Cuadernos del CISH, Año 3, N 4, La Plata, 1998.

“Cámpora al gobierno, Perón al poder. La tendencia revolucionaria del peronismo ante las elecciones del 11 de Marzo de 1973" En: Pucciarelli, A (ed.): La primacía de la política. Lanusse, Perón y la Nueva Izquierda en tiempos del GAN, Buenos Aires, Eudeba, 1999.

Levin, Florencia. Humor Político en tiempos de represión. Clarín, 1973-1983, Buenos Aires, Silgo XXI, 2013.

Pacheco, Julieta, "Acerca del programa de la organización Montoneros: ¿reformistas o revolucionarios?”, en: Trabajo y Sociedad N² 23, Santiago del Estero, 2014.

Schenider, Alejandro. "Cuando se hizo tronar el escarmiento. La política laboral de Juan D. Perón para disciplinar el movimiento obrero" En Ghigliani, P y Schneider, A: Sobre trabajadores y el mundo del trabajo en Argentina, Buenos Aires, Imago mundi, 2015

Schoentjes, Pierre. Politica de la Ironía, Paris, Ediciones du Seuil, 2001.

Seminara, Luciana. "Escribir las prácticas. Diálogos implícitos entre Montoneros y la organización Sabino Navarro”, En: Travesía N 16, Tucumán, 2014

Slipak, Daniela, Las revistas montoneras. Como la organización construyó su identidad a través de sus publicaciones, Buenos Aires, Siglo XXI, 2015

Sigal, Silvia y Verón, Eliseo, Perón o muerte. Los fundamentos discursivos del fenómeno peronista, Buenos Aires, Legasa, 2003

Stavale, Mariela. "Peronismo para la Liberación Nacional ¿y social? El vínculo peronismorevolución en las revistas Militancia Peronista para la Liberación y Envido, 1973”, En: Contemporánea $\mathrm{N}^{\circ}$ 7, Montevideo, 2016.

Steimberg, Oscar. "Sobre algunos temas y problemas del análisis del humor gráfico", En: Signo y seña. Facultad de Filosofía y Letras UBA, Buenos Aires, 2001 
Tortti, María Cristina. "La nueva izquierda argentina. La cuestión del peronismo y el tema de la revolución", en: Tortti, M.C. (dir), Chama Mauricio y Celentano, Adrián (co-dir) La Nueza Izquierda Argentina. Socialismo, Peronismo y Revolución, 1955-1976, Rosario: Ediciones Prohistoria, 2014

"Protesta social y nueva izquierda en la Argentina del Gran Acuerdo Nacional", en Pucciarelli, A (ed.) La primacía de la política. Lanusse, Perón y la Nueva Izquierda en tiempos del GAN, Buenos Aires, Eudeba, 1999.

Fuentes digitalizadas:

* Revista El Caudillo de la Tercera Posición. Disponible en: www.ruinasdigitales.com

* Revista El Descamisado, en: www.eltopoblindado.com

* Revista Militancia Peronista para la Liberación, en: www.eltopoblindado.com

* Perón, Juan Domingo. Discurso a los gobernadores, 2 de Agosto de 1973. En: www.ruinasdigitales.com

Entrevistas consultadas:

* Testimonio de Eduardo Duhalde en entrevista con Celecia Felipe y Waisberg, Pablo. En: La ley y las armas. Biografía de Rodolfo Ortega Peña, Buenos Aires, Ediciones Aguilar, 2007

* Testimonio de Marcelo Duhalde en entrevista con la autora, Buenos Aires, 2014

* Testimonio de Roberto Perdía en entrevista con Celecia, Felipe y Waisberg, Pablo, Ibid. 


\section{Anexo: Ilustraciones}

Fig. 1

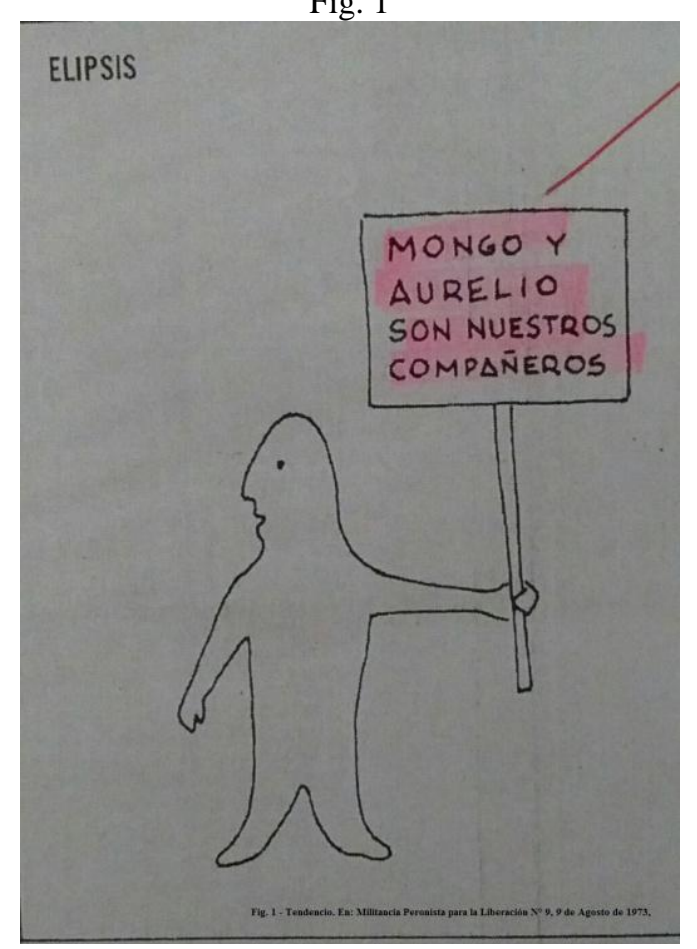

Fig.2

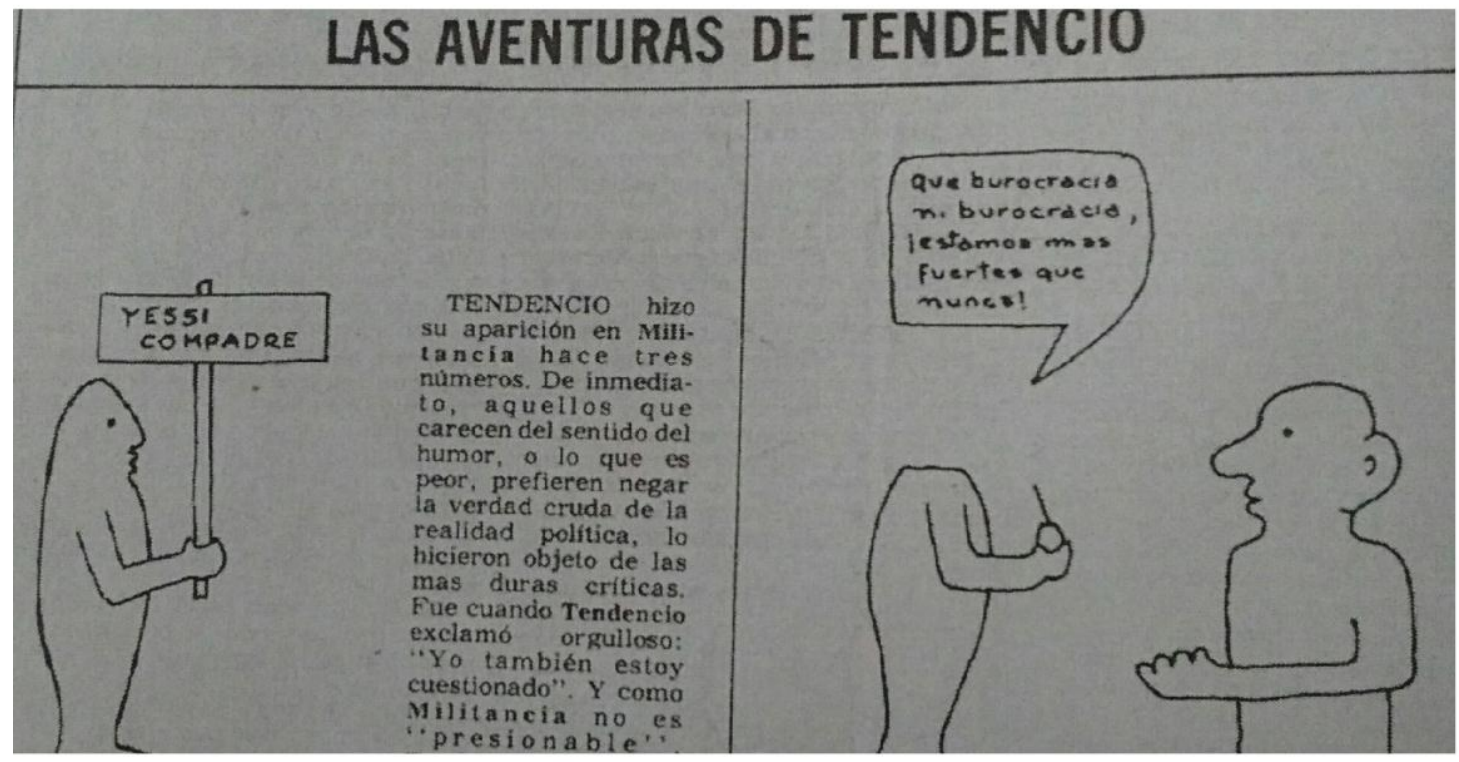

Fię, 2- Tendencio. En: Militancia Peronista para las Liberacíon No 10,16 de Aggosto de 1973, p:s? 
Fig. 3

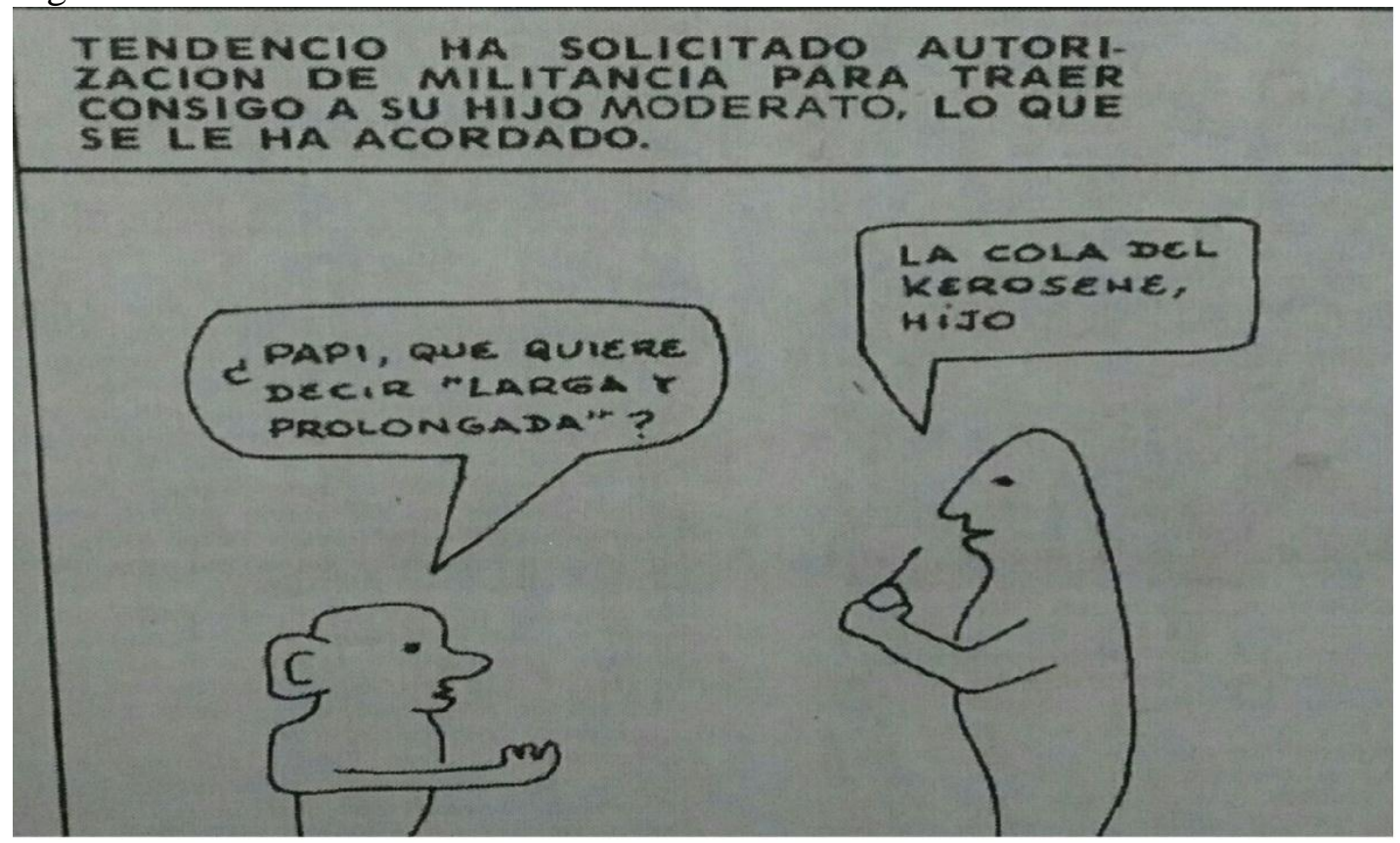

Fig. 3 - Tendencio. En: Militancia Peronista para la Liberación No 16,27 de Septiembre de 1973, P.: 7

Fig. 4

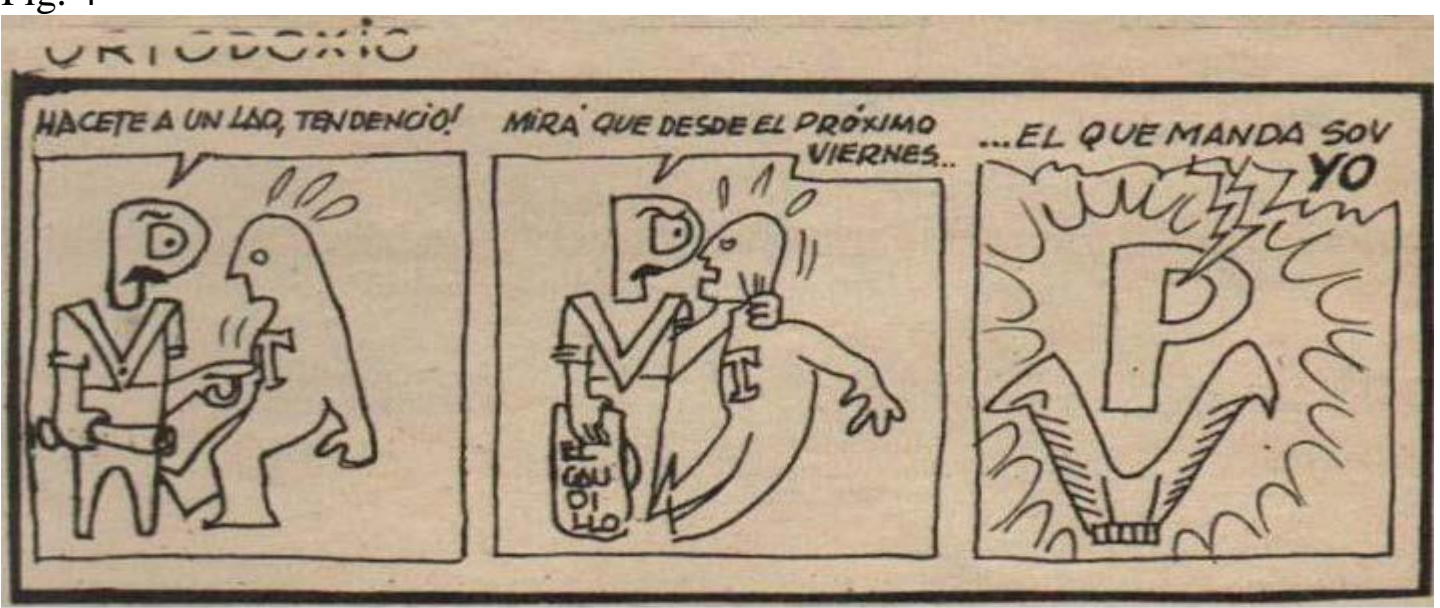

Figura 4 - Ortodoxio. En: El Caudillo de la Tercera Posición $N^{\circ}$ 6, 21 de Diciembre de 1973, P. 23. 
Fig. 5

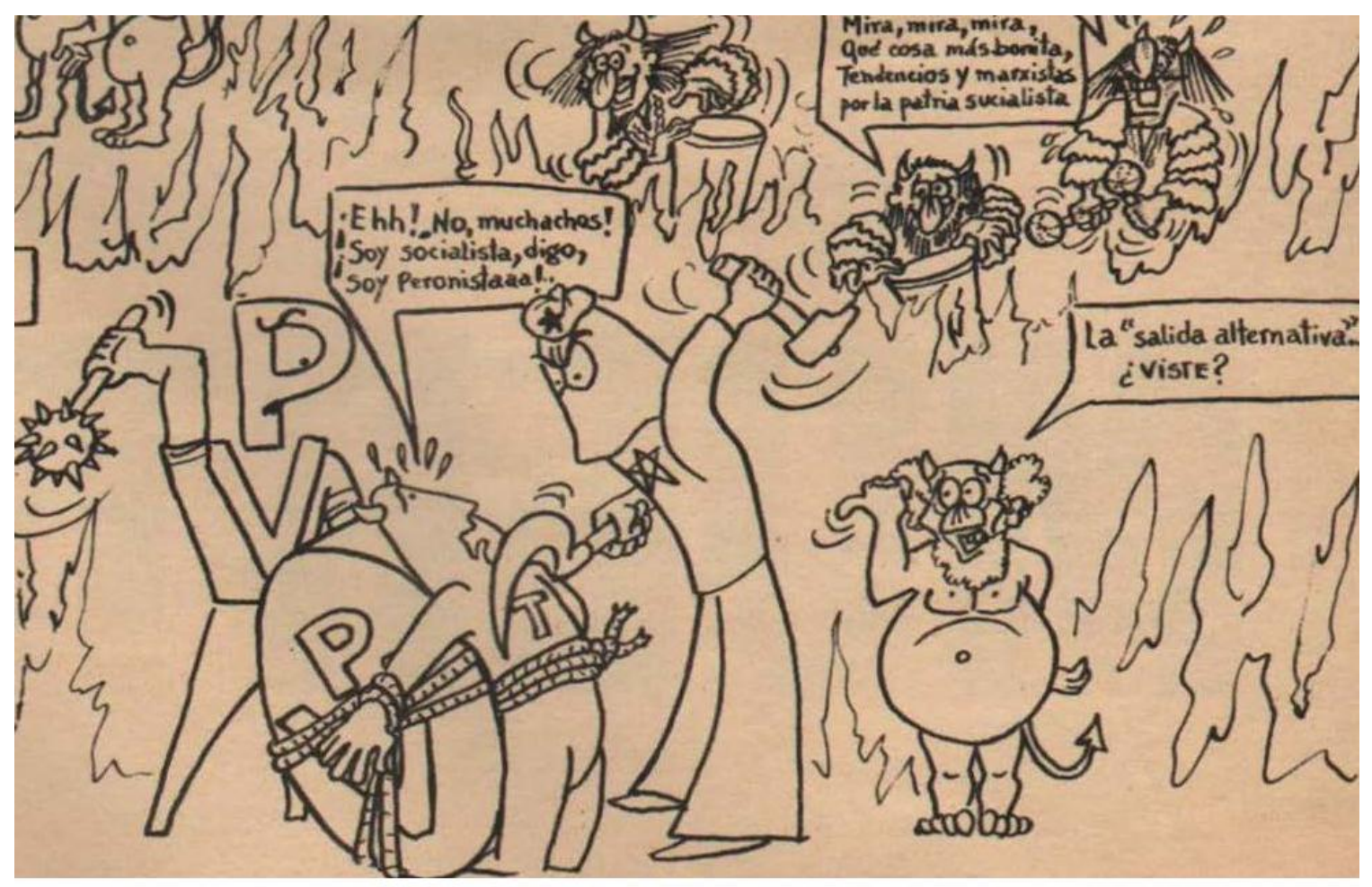

Fig.6

Fig. 5 - Ortodoxio. En: El Caudillo de la Tercera Posición No 14. 15 de Febrero de 1974. v.: 23

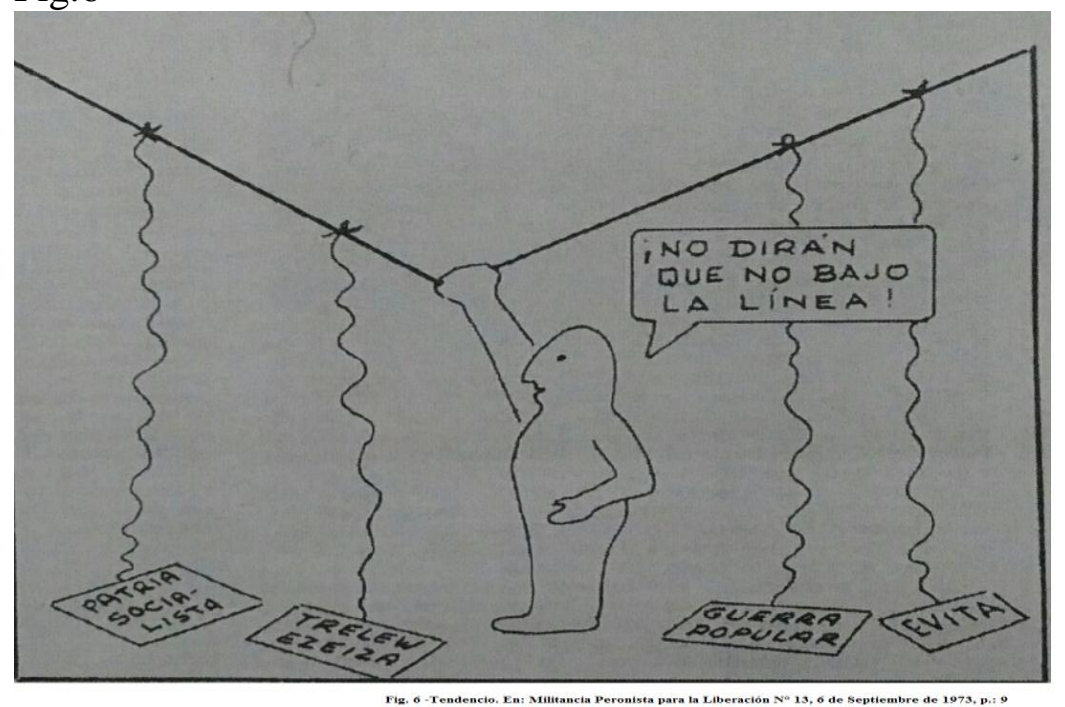


Fig.7

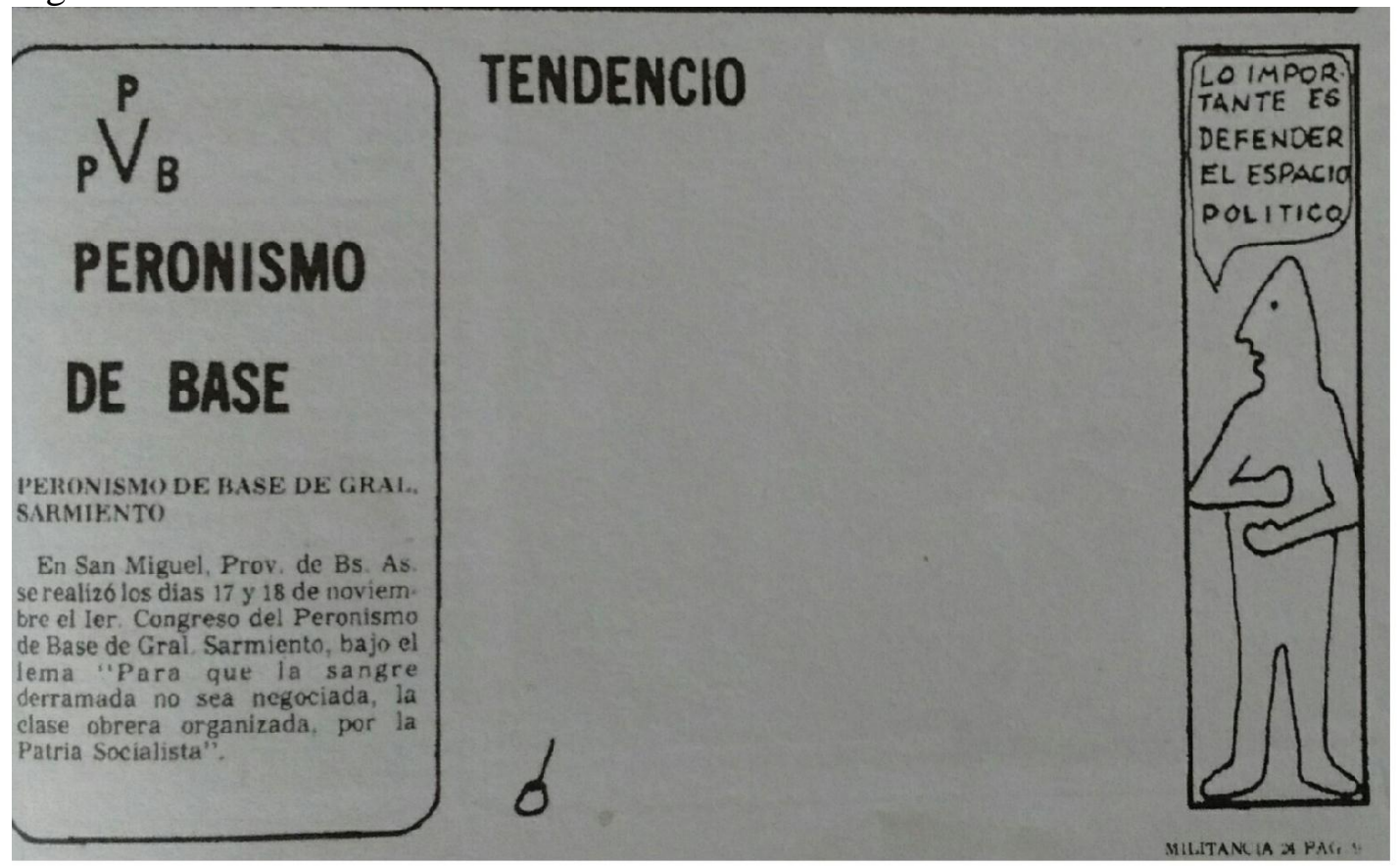

Fig. 7 - Tendencio. En: Militancia Peronista para la Liberación № 24,22 de Noviembre de 1073, p.: 9

Fig.8

\section{TENDENCIO}

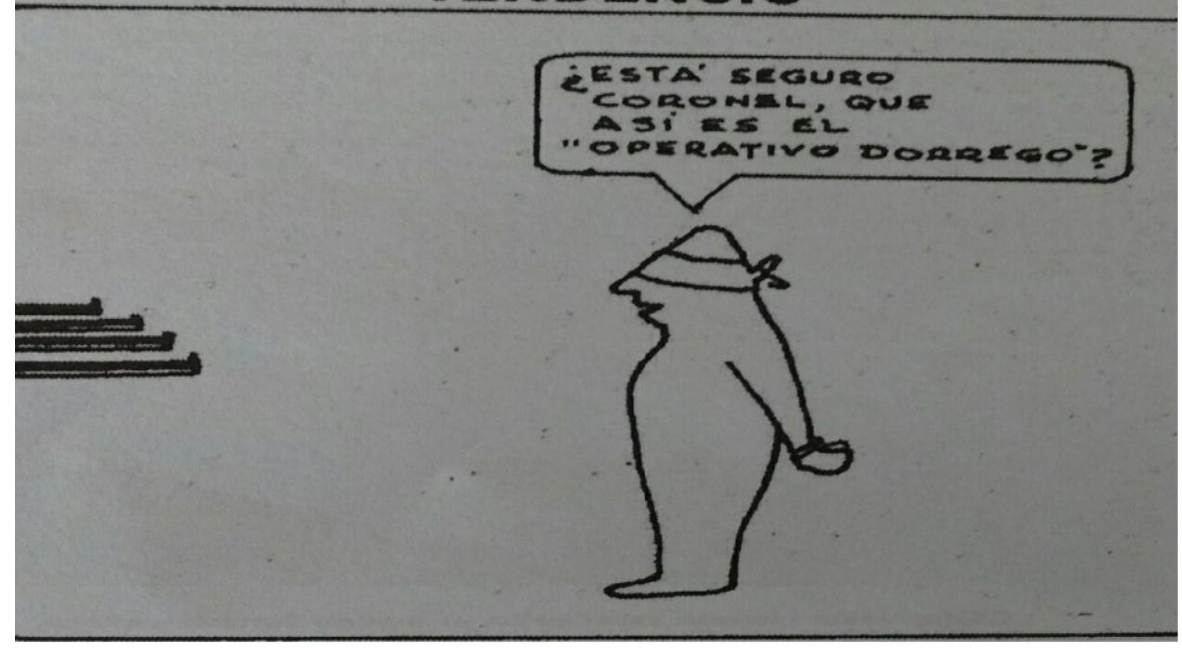

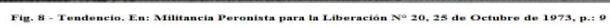

